Article

\title{
Chiral Aminophosphines as Catalysts for Enantioselective Double-Michael Indoline Syntheses
}

\author{
San N. Khong and Ohyun Kwon * \\ Department of Chemistry and Biochemistry, University of California, Los Angeles, CA 90095, USA \\ * Author to whom correspondence should be addressed; E-Mail: ohyun@chem.ucla.edu.
}

Received: 23 March 2012; in revised form: 19 April 2012 / Accepted: 23 April 2012 /

Published: 11 May 2012

\begin{abstract}
The bisphosphine-catalyzed double-Michael addition of dinucleophiles to electron-deficient acetylenes is an efficient process for the synthesis of many nitrogencontaining heterocycles. Because the resulting heterocycles contain at least one stereogenic center, this double-Michael reaction would be even more useful if an asymmetric variant of the reaction were to be developed. Aminophosphines can also facilitate the double-Michael reaction and chiral amines are more readily available in Nature and synthetically; therefore, in this study we prepared several new chiral aminophosphines. When employed in the asymmetric double-Michael reaction between ortho-tosylamidophenyl malonate and 3-butyn-2-one, the chiral aminophosphines produced indolines in excellent yields with moderate asymmetric induction.
\end{abstract}

Keywords: double-Michael reaction; chiral aminophosphines; anchimeric assistance; indoline

\section{Introduction}

Most chiral natural products exist in enantiomerically pure forms, synthesized in Nature mostly through enzyme-mediated catalysis [1]. Not surprisingly, enantioselective catalysis processes were long believed, up until the early 1900s, to be accessible using only natural enzymes, until Bredig's attempts at (i) kinetic resolution of racemic camphorcarboxylic acid through selective decarboxylation in a chiral medium (e.g., L- or D-limonene) or in the presence of a chiral alkaloid catalyst (e.g., nicotine or quinidine) [2-5] and (ii) asymmetric synthesis of mandelonitrile through the addition of $\mathrm{HCN}$ to benzaldehyde in the presence of a cinchona alkaloid catalyst (e.g., quinidine or quinine) $[2,3,6]$. 
Although these effortful studies were conceptually groundbreaking, the enantioselectivity achieved was synthetically impractical $(<10 \%$ ee). A synthetically useful enantiomeric excess of $74 \%$ was first achieved by Pracejus in the synthesis of (-)-methyl $\alpha$-phenylpropionate from methyl phenyl ketene and methanol with $O$-acetylquinine as the catalyst [7]. Catalytic asymmetric synthesis was established as a reliable and practical approach when Knowles reported, in the late 1960s and early 1970s, the first asymmetric hydrogenations catalyzed by transition metals bearing chiral phosphine ligands [8-13]. Shortly afterward, a great number of chiral phosphine ligands were developed to provide excellent enantioselectivity in transition metal-catalyzed hydrogenations [14,15]. The major disadvantage of transition metal catalysis, however, is that traces of toxic heavy metals can be left behind in the final products.

In the early 1970s, L-proline-mediated asymmetric Robinson annulation was first reported [16-19], although the synthesis community paid very little attention to it because the reaction was considered a novelty. Since the concept of organocatalysis - the utilization of metal-free small organic molecules as catalysts for organic transformations - was developed and recognized in the late 1990s, there has been an explosion of research in the field of organocatalysis [20-22], which is now widely considered as a third main branch of research in asymmetric synthesis, beside enzymatic catalysis and organometallic catalysis.

A chiral organocatalyst can render enantioinduction (asymmetric induction) through a few modes, including covalent bonding, ionic bonding, and hydrogen bonding (Figure 1a-c) [21]. In 2007, we reported a phosphine-catalyzed double-Michael addition in which a bisphosphine was the best catalyst [23-25]. We suggested that anchimeric assistance by the other tethered phosphino group stabilized the resultant phosphonium cation in the transitional intermediates, leading to a higher yield of the double-Michael adduct. Because of the rigid architecture provided by intramolecular anchimeric assistance, we suspected that a chiral element at the terminus of the non-reactive phosphino group would be likely to endow the reactive phosphonium center with steric bias, potentially leading to a new mode of enantioinduction (Figure 1d). Practically, the synthesis of chiral bisphosphines is often challenging because it requires careful handling of pyrophoric and air-sensitive phosphorus-containing intermediates.

As a variant of the bisphosphine catalyst, we sought an equivalent to a phosphino group that would be easy to handle yet stabilize the tethered phosphonium cation through anchimeric assistance. In Verkade's proazaphosphatrane [26-28], the nitrogen atom could efficiently stabilize the resultant protonated phosphonium center, making it a super base (Figure 2a). Therefore, we expected an aminophosphine - with an amino group replacing a tethered phosphino group in the bisphosphine- To function much like a bisphosphine when catalyzing double-Michael additions (Figure 2b). Less-toxic and more air-stable than phosphines, amines also have advantages in terms of their synthesis and storage. Furthermore, many diverse chiral amines are readily available commercially from natural sources. Appending a customized chiral element to an achiral amine is also easy to achieve through simple alkylation, imine reduction, or peptide coupling/reduction. Therefore, we proceeded to synthesize a variety of chiral aminophosphines to determine if they could result in enantioinduction via anchimeric assistance and concurrently to develop an asymmetric variant of the double-Michael reaction. 
Figure 1. Modes of enantioselective induction provided by organocatalysts through (a) covalent bonding; (b) ionic bonding; (c) hydrogen bonding; and (d) intramolecular anchimeric assistance.

a.<smiles>[R]C=CC=O</smiles>

substrate<smiles>CN1C(=O)C(Cc2ccccc2)NC1C(C)(C)C</smiles>

catalyst

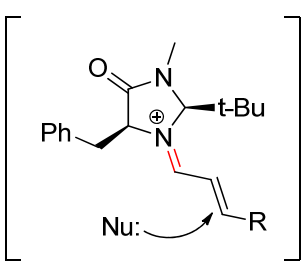

transitional intermediate

b.<smiles>[R]ON=[V]</smiles>

$\mathrm{X}=\mathrm{O}, \mathrm{NR}$

substrate

c.

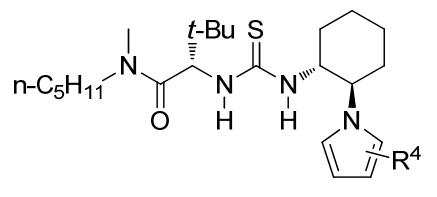

catalyst<smiles>CN(C)C(=O)C(NC(=S)N[C@H]1CCCC[C@H]1N)C(C)(C)C</smiles>

catalyst<smiles>[R][R]([R])CCC[PH2+]</smiles>

catalyst

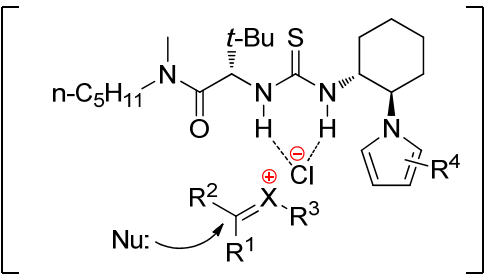

transitional intermediate

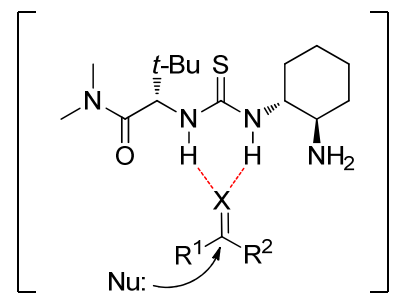

transitional intermediate

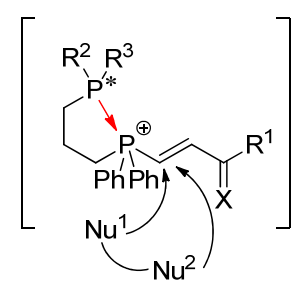

transitional intermediate

Figure 2. Possible intramolecular anchimeric assistance. (a) Verkade's protonated proazaphosphatrane; (b) Utilization of a chiral aminophosphine instead of a chiral bisphosphine.

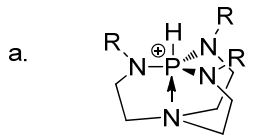

protonated Verkade's proazaphosphatrane

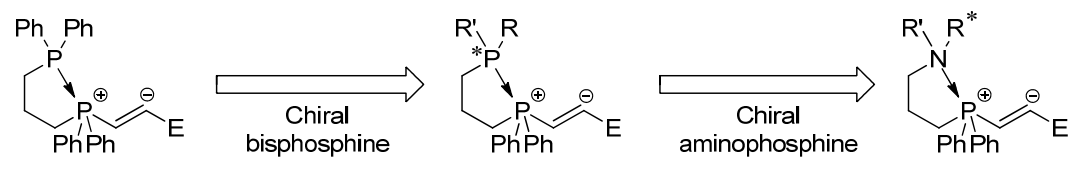


We propose a reaction mechanism for the double-Michael reaction that occurs via pathway $\mathbf{A}$, in which the cyclization is accomplished through direct intramolecular $S_{N} 2$ displacement of the phosphonium cation (Scheme 1). Alternatively, the reaction could possibly follow mechanistic pathway $\mathbf{B}$, in which the intermediate phosphonium zwitterions serve as a Brønsted base and the resulting phosphonium species as a counter cation of the reactive intermediate anions (Scheme 1). In either case, the most important factor affecting the success of cyclization would be the stability of the phosphonium species generated along the pathway [23]. If the reaction employed a chiral aminophosphine catalyst, the enantioselectivity would probably be induced via anchimeric assistance of the amine in stabilizing the quaternary phosphonium center.

Scheme 1. Possible mechanistic pathways for the double-Michael reaction.
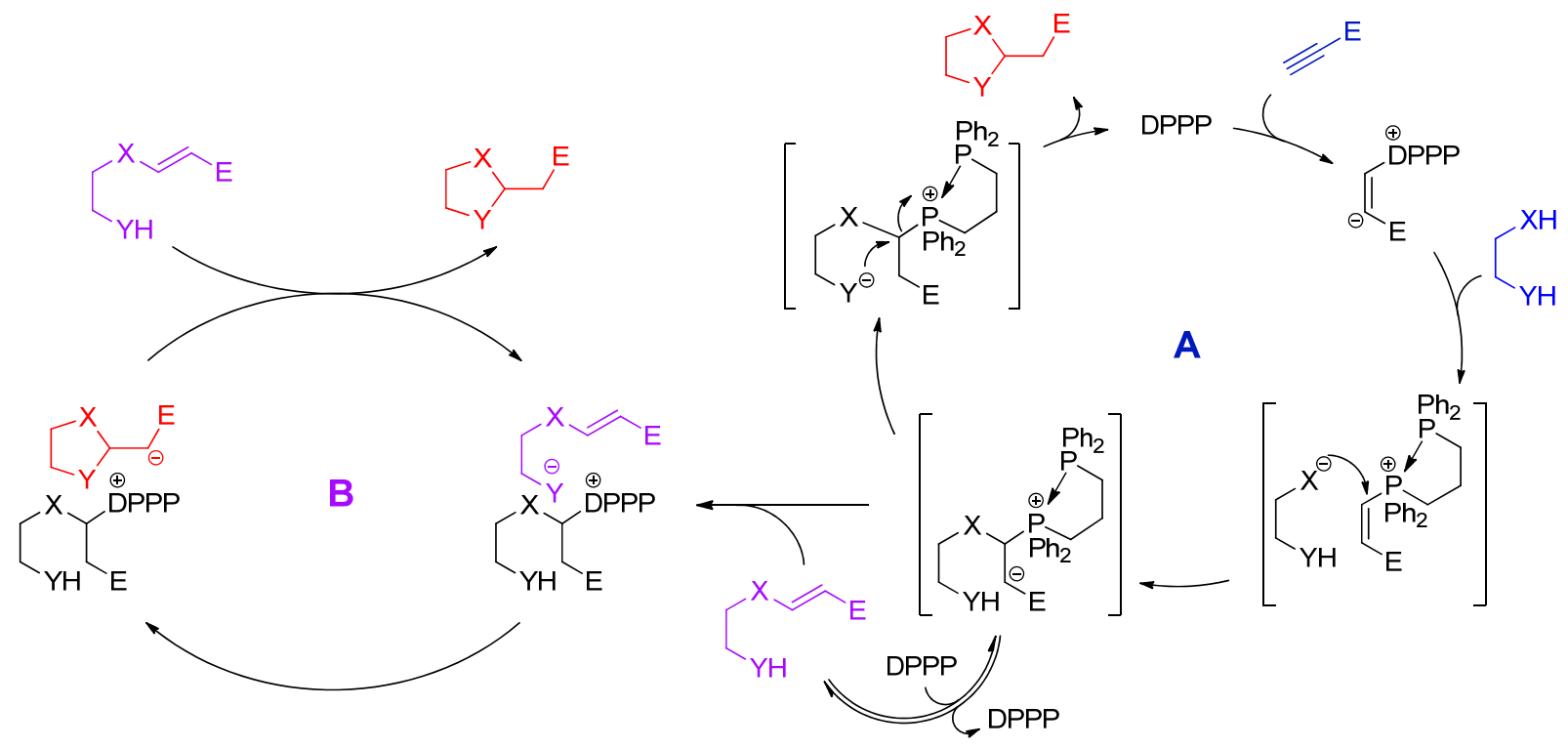

\section{Results and Discussion}

Chiral bisphosphines featuring $C_{2^{-}}$or local $C_{2}$-symmetry, obtained directly from commercial sources, were tested in the double-Michael reaction between $o$-( $p$-tosylamido)phenylmalonate (1a) and 3-butyn-2-one (2a) to form the indoline product 3aa (Table 1) [29]. The optimal conditions for the reaction catalyzed by diphenylphosphinopropane (DPPP) required an elevated temperature (entry 1). Employing chiral bisphosphines as catalysts, the double-Michael reaction at elevated temperature exhibited no enantioinduction (entries 2, 4, and 6). At room temperature, however, the reactions exhibited low levels of enantioselectivity (entries 3, 5, 7, and 8). Employing $(S, S)$-DIOP as a chiral catalyst resulted in no desired product (entry 9). Use of the chiral bisamine (DHQ) ${ }_{2} \mathrm{PHAL}$ provided a lower yield, with no improvement in enantioselectivity (entry 10$)$. Catalysis by the $(R, R)-\mathrm{DACH}-$ napthyl Trost ligand, a chiral bisamidophosphine, resulted in a much inferior yield, with no enantioselectivity (entry 11). Surprisingly, the aminophosphine 42, which has the same rigid carbon framework and distance between the two functional groups as that in DIOP, catalyzed the reaction successfully, providing a good yield and a slightly improved enantioselectivity (entries 9 and 12). This result offered us hope that we could develop an asymmetric variant of the double-Michael addition using a chiral aminophosphine as the catalyst. 
Table 1. Preliminary screening with commercially available chiral bisphosphines [29].

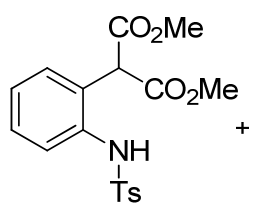

$1 \mathbf{a}$

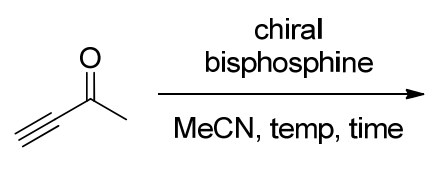

$2 \mathbf{a}$

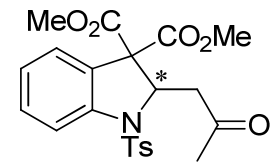

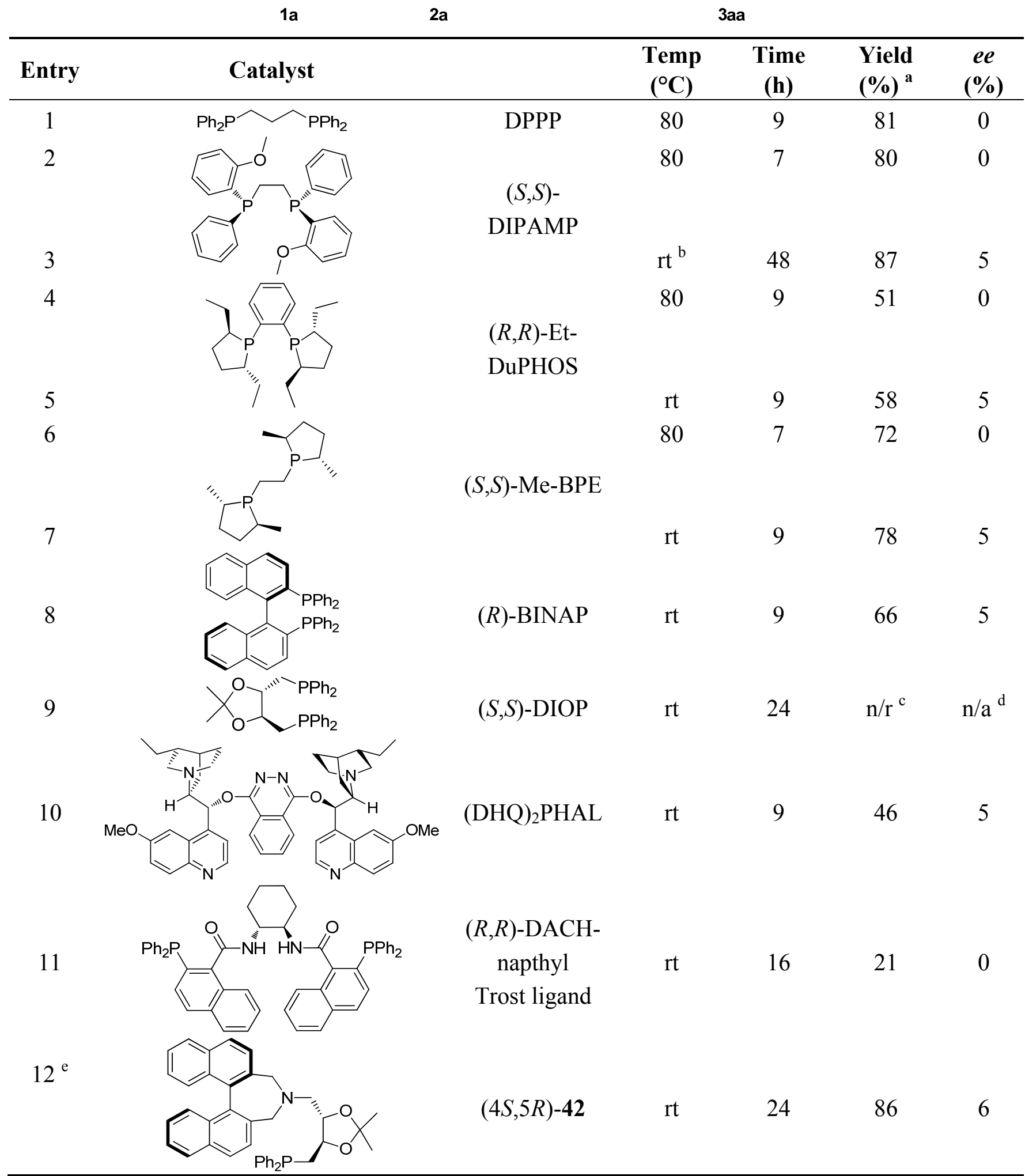

${ }^{a}$ Isolated yield. ${ }^{b} \mathrm{rt}=$ Room temperature. ${ }^{\mathrm{c}} \mathrm{n} / \mathrm{r}=$ No reaction. ${ }^{\mathrm{d}} \mathrm{n} / \mathrm{a}=$ Not applicable. ${ }^{\mathrm{e}}$ Synthetically prepared phosphine. 


\subsection{Synthesis of Aminophosphines}

Scheme 2 outlines our approach for the syntheses of three-carbon-tethered aminophosphines. It starts with acylation of a primary or secondary amine with acryloyl chloride to form the corresponding acrylamide, followed by Michael addition of diphenylphosphine to generate an amidophosphine [30], which would eventually be converted to the aminophosphine through $\mathrm{LiAlH}_{4}$-mediated reduction. Because the chirality of the amine would be endowed to the reactive phosphonium center, our goal was to identify potential chiral amines from either commercial or synthetic sources. Notably, we could also test the amidophosphine, an immediate precursor of the aminophosphine, for its enantioinduction ability in double-Michael reactions.

Scheme 2. General route toward a 3-amino-1-phosphinopropane.

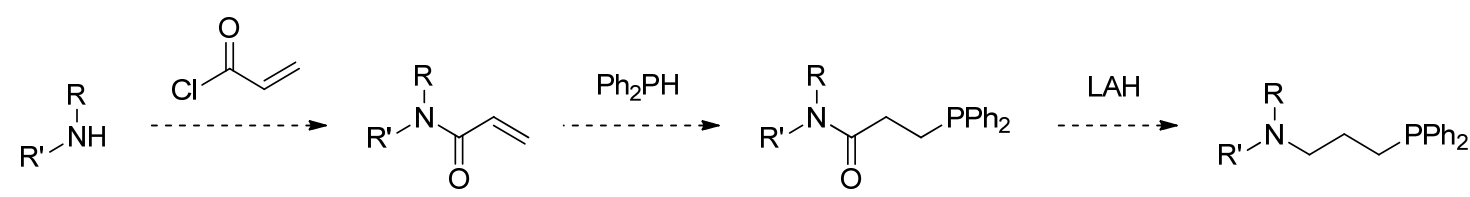

\subsection{Syntheses of Chiral Aminophosphines from a Commercially Available Chiral Amine}

To test the viability of the proposed synthetic route, we employed an inexpensive chiral amine 1 to synthesize the chiral aminophosphine 5 (Scheme 3). The chiral amine $\mathbf{1}$ was first N-methylated via formylation followed by $\mathrm{LiAlH}_{4}$-mediated reduction to furnish the chiral amine 2, which we then treated with acryloyl chloride to prepare the acrylamide substrate $\mathbf{3}$ for subsequent Michael addition of diphenylphosphine. We obtained our target aminophosphine 5 after $\mathrm{LiAlH}_{4}$-mediated reduction of the Michael adduct amidophosphine 4. This synthetic route was reliable and the purification of the products was straightforward. When testing the chiral aminophosphine $\mathbf{5}$ in the double-Michael addition, we detected an enantioselectivity of 5\% ee. The reaction yield was, however, low, due to our early termination of the reaction to determine the enantioselectivity (Table 2, entry 1).

Shortening the tether length in the aminophosphine would bring the two functional groups in closer proximity, potentially enhancing the interaction between amino and phosphino centers and forming more-rigid reaction intermediates. Accordingly, we synthesized the aminophosphine 7 from the amine 2 through coupling with bromoacetyl bromide, substitution with potassium diphenylphosphide, and $\mathrm{LiAlH}_{4}$-mediated reduction of the amidophosphine 6. To our dismay, when we employed this chiral aminophosphine 7 in the double-Michael reaction, the enantioselectivity of the reaction was barely detectable (Table 2, entry 2). We surmised that it might be more advantageous to feature a free $\mathrm{N}-\mathrm{H}$ group in the aminophosphine to provide a site for hydrogen bonding to the $\mathrm{C}=\mathrm{O}$ oxygen atom of the alkynone substrate [31-35]; such hydrogen bonding would bring the two functional groups closer together in the transition intermediate (Figure 3). Thus, we treated the chiral amine 1 with acryloyl chloride to prepare the acrylamide 8; Michael addition with diphenylphosphine under basic conditions furnished the amidophosphine 9, which underwent $\mathrm{LiAlH}_{4}$-mediated reduction to generate the target chiral aminophosphine 10. The enantioinduction in the double-Michael reaction catalyzed by the aminophosphine $\mathbf{1 0}$ was similarly low to that induced by the aminophosphine catalyst $\mathbf{5}$, which features no $\mathrm{N}-\mathrm{H}$ bond (Table 2, entry 3). Interestingly, the amidophosphines $\mathbf{4}, \mathbf{6}$, and $\mathbf{9}$ also catalyzed 
the double-Michael reaction, with yields and enantioselectivities comparable to those of their corresponding aminophosphines (Table 2, cf. entries 1-3 and 14-16).

Scheme 3. Syntheses of two- and three-carbon-tethered aminophosphines.

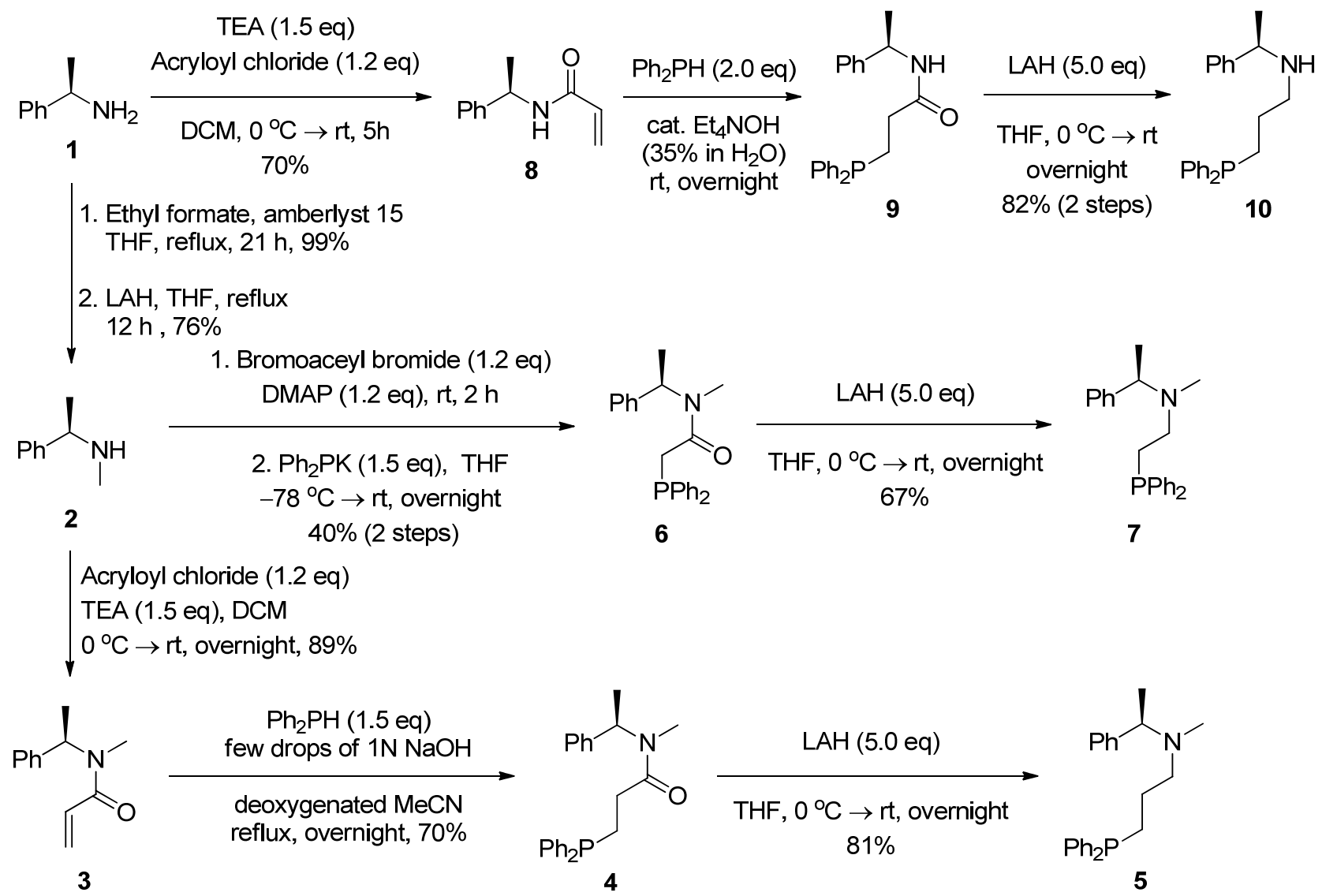

Table 2. Screening with synthetic chiral aminophosphines and amidophosphines.

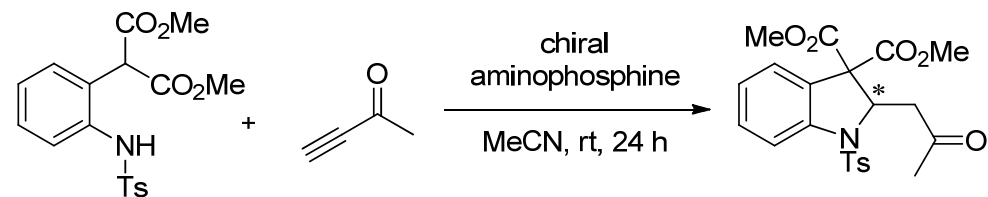

$1 a \quad 2 a$

\begin{tabular}{|c|c|c|c|c|c|c|c|}
\hline Entry & Aminophosphine & $\begin{array}{l}\text { Yield } \\
(\%)^{a}\end{array}$ & $\begin{array}{c}e e \\
(\%)^{b}\end{array}$ & Entry & Amidophosphine & $\begin{array}{l}\text { Yield } \\
(\%)^{a}\end{array}$ & $\begin{array}{c}e e \\
(\%)\end{array}$ \\
\hline $1^{b}$ & $\mathrm{PPh}_{2}$ & 46 & 5 & 14 & & 39 & 5 \\
\hline 2 & & 86 & 0 & 15 & & 95 & 0 \\
\hline 3 & & 84 & 4 & 16 & & 85 & 4 \\
\hline 4 & & 83 & 3 & 17 & & 91 & 0 \\
\hline
\end{tabular}


Table 2. Cont.

\begin{tabular}{|c|c|c|c|c|c|c|c|}
\hline Entry & Aminophosphine & $\begin{array}{l}\text { Yield } \\
(\%)^{a}\end{array}$ & $\begin{array}{c}e e \\
(\%)^{b} \\
\end{array}$ & Entry & Amidophosphine & $\begin{array}{l}\text { Yield } \\
(\%)^{a} \\
\end{array}$ & $\begin{array}{c}e e \\
(\%)^{b}\end{array}$ \\
\hline 5 & & 89 & 6 & 18 & & 94 & 9 \\
\hline 6 & & 74 & 2 & 19 & & 86 & 0 \\
\hline 7 & & 73 & 2 & 20 & $\mathrm{n} / \mathrm{a}^{\mathrm{c}}$ & $\mathrm{n} / \mathrm{a}^{\mathrm{d}}$ & $\mathrm{n} / \mathrm{a}^{\mathrm{d}}$ \\
\hline 8 & & 84 & -9 & 21 & $\mathrm{n} / \mathrm{a}^{\mathrm{c}}$ & $\mathrm{n} / \mathrm{a}^{\mathrm{d}}$ & $\mathrm{n} / \mathrm{a}^{\mathrm{d}}$ \\
\hline 9 & & 91 & -2 & 22 & $\mathrm{n} / \mathrm{a}^{\mathrm{c}}$ & $\mathrm{n} / \mathrm{a}^{\mathrm{d}}$ & $n / a^{d}$ \\
\hline 10 & & 83 & 0 & 23 & $\mathrm{n} / \mathrm{a}^{\mathrm{c}}$ & $\mathrm{n} / \mathrm{a}^{\mathrm{d}}$ & $\mathrm{n} / \mathrm{a}^{\mathrm{d}}$ \\
\hline 11 & & 86 & -6 & 24 & $\mathrm{n} / \mathrm{a}^{\mathrm{c}}$ & $\mathrm{n} / \mathrm{a}^{\mathrm{d}}$ & $\mathrm{n} / \mathrm{a}^{\mathrm{d}}$ \\
\hline 12 & & 69 & 10 & 25 & & 81 & 0 \\
\hline 13 & & 90 & 3 & 26 & & 88 & 3 \\
\hline
\end{tabular}

${ }^{\mathrm{a}}$ Isolated yield. ${ }^{\mathrm{b}}$ Reaction time was $6 \mathrm{~h} .{ }^{\mathrm{c}} \mathrm{n} / \mathrm{a}=$ Not available. ${ }^{\mathrm{d}} \mathrm{n} / \mathrm{a}=$ Not applicable.

Figure 3. Transition intermediate featuring intramolecular hydrogen bonding.<smiles>CC1=CC[Pb]2(C=C1)CCCN([C@H](C)c1ccccc1)C2</smiles>

$\mathrm{PhPh}$

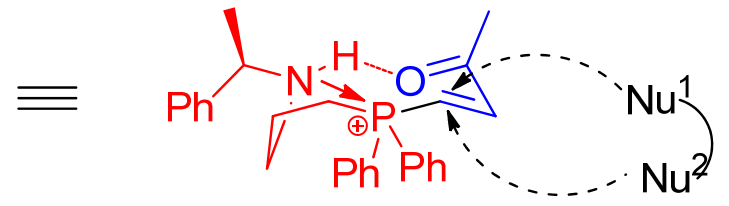

One possible transition state predicted by the hand-held model kit 


\subsection{Syntheses of L-Proline-Derived Chiral Aminophosphines}

Because our simple versions of aminophosphines with acyclic chiral amine motifs did not work well as catalysts for the asymmetric double-Michael additions, we decided to insert a more-rigid chiral amine motif derived from L-proline, which has been employed frequently in asymmetric reactions [36,37]. $O$-Benzyl aminophosphine 17 became our first synthetic target (Scheme 4). After a simple sequence of $\mathrm{LiAlH}_{4}$-mediated reduction, N-Boc protection, and O-benzylation, we obtained the globally protected L-prolinol 14. The Boc group of $\mathbf{1 4}$ was released under acidic conditions and the resulting free amine converted to the acrylamide $\mathbf{1 5}$ upon treatment with acryloyl chloride. Michael addition of diphenylphosphine to the acrylamide $\mathbf{1 5}$ under basic conditions cleanly afforded the amidophosphine 16, which underwent $\mathrm{LiAlH}_{4}$-mediated reduction to yield the target aminophosphine 17. Unfortunately, we detected only 3\% ee when applying the aminophosphine 17 to catalyze the double-Michael reaction. The corresponding amidophosphine $\mathbf{1 6}$ provided undetectable enantioselectivity, although the product yield was higher than that obtained with the aminophosphine 17 (Table 2, entries 4 and 17).

Scheme 4. L-Proline-derived chiral aminophosphines.

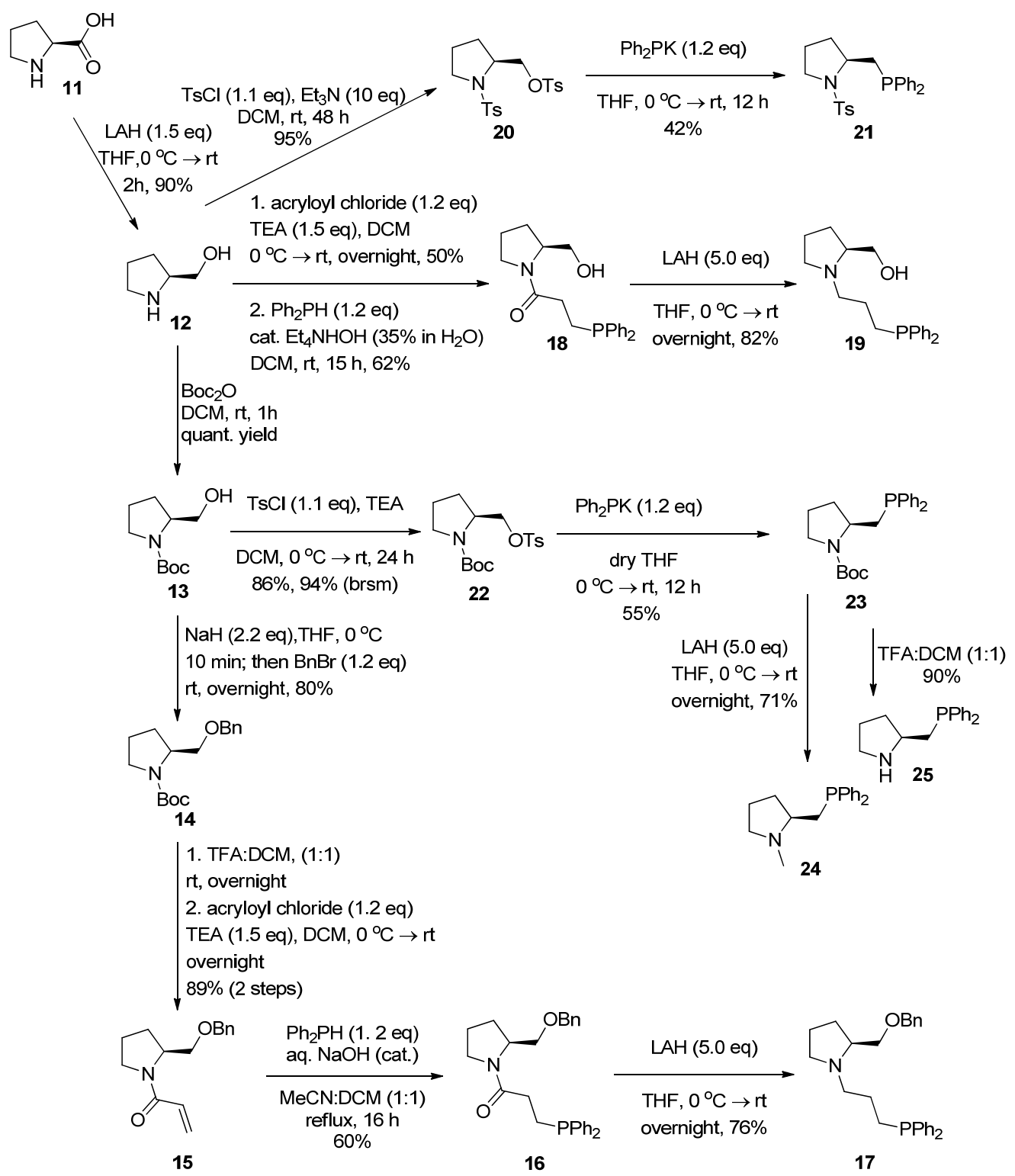


We suspected that unmasking the $\mathrm{OH}$ group in the aminophosphine $\mathbf{1 7}$ might potentially provide hydrogen bonding to the $\mathrm{C}=\mathrm{O}$ oxygen atom in the alkynone substrate, possibly helping to lock the reaction intermediates into a more-rigid conformation and, hopefully, create a more-asymmetric environment in the subsequent steps toward the final product (Figure 4) [31-35]. The hydroxymethyl aminophosphine 19 was quickly accessible from the unprotected L-prolinol 12 through the sequence of $\mathrm{N}$-acryloylation, Michael addition of diphenylphosphine, and $\mathrm{LiAlH}_{4}$-mediated reduction. The resulting enantioselectivities were slightly increased and encouraging: $6 \%$ ee for the aminophosphine 19 and 9\% ee for the corresponding amidophosphine 18 (Table 2, entries 5 and 18). Notably, the yield and enantioselectivity provided by the amidophosphine $\mathbf{1 8}$ were superior to those induced by the aminophosphine 19 in the double-Michael addition.

Figure 4. Proposed conformation of an intermediate stabilized through intramolecular hydrogen bonding and intramolecular anchimeric assistance.

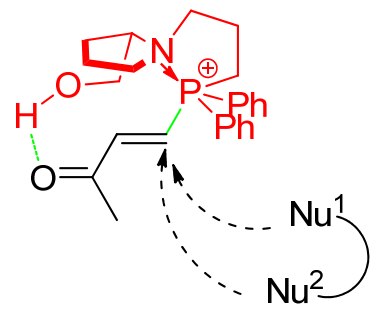

\author{
One possible transition state \\ predicted using the hand-held model kit
}

Another scaffold, based on amino acid-derived phosphines, has recently been employed in asymmetric nucleophilic catalysis [33-35]. In this scaffold, the two functional groups are tethered through two carbon atoms, with the chiral element residing on the tether bridge. The aminophosphines 21 and 23-25 are derived accordingly from L-proline. The $N$-Tosyl aminophosphine 21 was quickly prepared from L-prolinol 12 after global tosylation and subsequent direct displacement of the tosylate group with potassium diphenylphosphide. The aminophosphines $\mathbf{2 4}$ and $\mathbf{2 5}$ were both obtained from the aminophosphine 23, through $\mathrm{LiAlH}_{4}$-mediated reduction and acidic Boc-deprotection, respectively; the aminophosphine $\mathbf{2 3}$ itself was quickly accessible through tosylation of $N$-Boc-L-prolinol $\mathbf{1 3}$ and subsequent substitution with potassium diphenylphosphide. To our dismay, these L-proline-derived aminophosphines provided generally unsatisfactory levels of enantioselectivity in the double-Michael reaction, with the exception of $\mathbf{2 3}$ (Table 2, entries 8-11).

Introduction of the more substituents to the chiral element in L-proline-derived aminophosphine could possibly enhance the catalyst enantioinduction. Aminophosphine $\mathbf{3 1}$ and $\mathbf{3 2}$ were thus synthesized as illustrated in Scheme 5. $\alpha, \alpha$-Diphenyl L-prolinol trimethylsilyl ether 28, which was easily prepared from L-proline (11) using a reported procedure, was subjected to the aforementioned route of phosphine synthesis including acryloylation and Michael-addition of diphenylphosphine. Unexpectedly, TMS protecting group was cleaved under basic Michael-addition condition to yield the hydroxy amidophosphine 30. The reintroduction of the silyl protecting group to amidophosphine $\mathbf{3 0}$ was not achievable due to the hydrolysis of the product during chromatography. Amidophosphine 30 was then set forward to LAH reduction to provide aminophosphine $\mathbf{3 1}$ which could be silylated to furnish $O$-TMS aminophosphine 32. Yet, the application of aminophosphine $\mathbf{3 1}$ and $\mathbf{3 2}$ to the doubleMichael reaction only provided lower reaction yield and enantioselectivity (Table 2, entries 6 and 7). 
Likewise, amidophosphine $\mathbf{3 0}$ resulted in no enantioinduction despite higher yield than the corresponding aminophosphine $\mathbf{3 1}$ in the double-Michael reaction (Table 2, entry 19).

Scheme 5. Elaboration of an L-proline-derived aminophosphine.

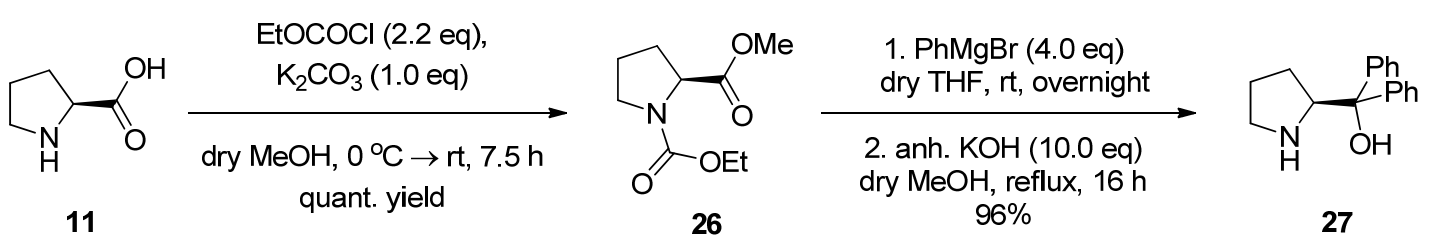

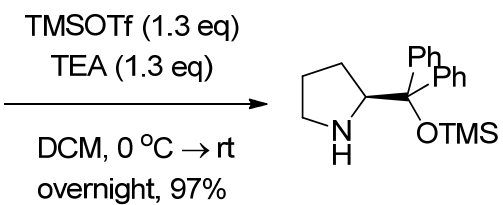

28 acryloyl chloride (1.2 eq) $\operatorname{TEA}(1.5 \mathrm{eq})$

$\mathrm{DCM}, 0^{\circ} \mathrm{C} \rightarrow \mathrm{rt}, 6 \mathrm{~h}$ $81 \%$

(2)

29

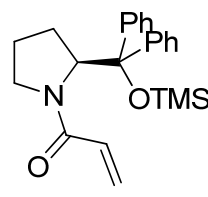<smiles>O=C(CCc1ccccc1)N1CCCC1C(O)(c1ccccc1)c1ccccc1</smiles>

$\operatorname{TMSOTf}(1.3 \mathrm{eq})$ TEA (1.3 eq) hydrolysis of product back $\overrightarrow{\mathrm{DCM}, \mathrm{O}^{\circ} \mathrm{C} \rightarrow \mathrm{rt}, 36 \mathrm{~h}} \quad \begin{gathered}\text { to starting material upon } \\ \text { chromatography }\end{gathered}$ 30

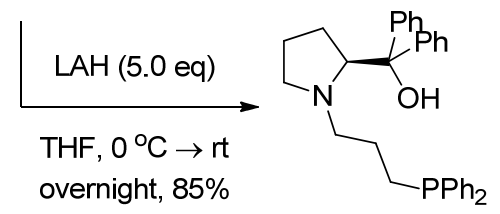
31

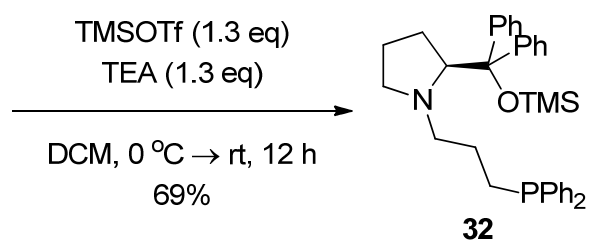

\subsection{Syntheses of Binol-Derived Chiral Aminophosphines}

Because the L-proline-derived aminophosphines were not satisfactory sources of asymmetric induction in the double-Michael reaction, we sought to prepare binol-derived aminophosphines featuring local $C_{2}$ symmetry on the amino moiety. Chiral binol and its derivatives have been used as sources of asymmetry in several chiral catalysts [38-41]; therefore, we selected binol as our first choice for the preparation of $C_{2}$-symmetric amine-containing aminophosphines. Scheme 6 outlines our synthesis of the aminophosphine 41. Within five steps, using a known procedure, we obtained the local $C_{2}$-symmetric amine 38 from commercially available (S)-binol (33). We subjected the crude product of the amine 38 directly to acryloylation to cleanly yield the acrylamide 39. Subsequent Michael addition of diphenylphosphine and $\mathrm{LiAlH}_{4}$-mediated reduction afforded the amidophosphine $\mathbf{4 0}$ and the aminophosphine 41, respectively. Our earlier version of the binol-derived aminophosphine 42 (Table 1, entry 18) is distinct from aminophosphine $\mathbf{4 1}$ in that the latter possesses a shorter, more-flexible tethering carbon atom chain. The aminophosphine 41 provided better enantioselectivity toward the double-Michael reaction, albeit with lower yield, than the aminophosphine 42 (cf. Table 1, entry 12 with Table 2, entry 12). The amidophosphine 40, however, provided undetectable enantioselectivity in the double-Michael reaction, even though its reaction yield was higher than that of the aminophosphine 41 (Table 2, entry 25). 
Scheme 6. Synthesis of a binol-derived aminophosphine.<smiles>Oc1ccc2ccccc2c1-c1c(O)ccc2ccccc12</smiles>

33

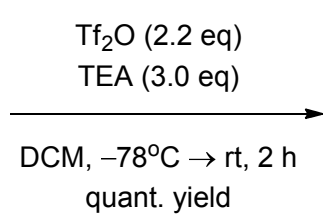

quant. yield

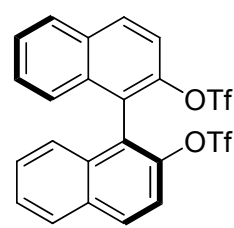

34

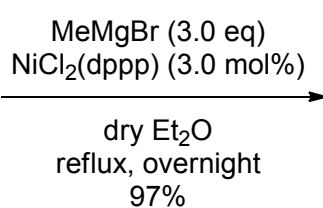

$97 \%$

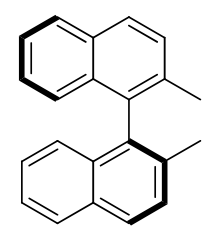

35
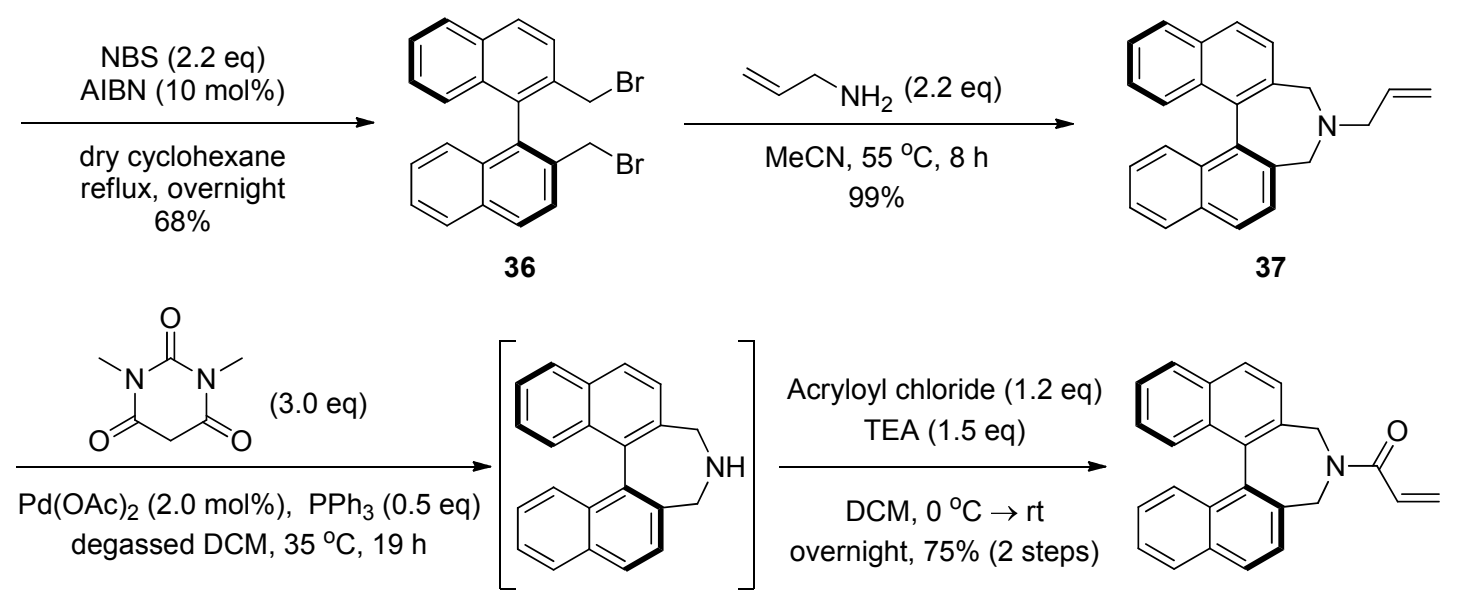

38

39
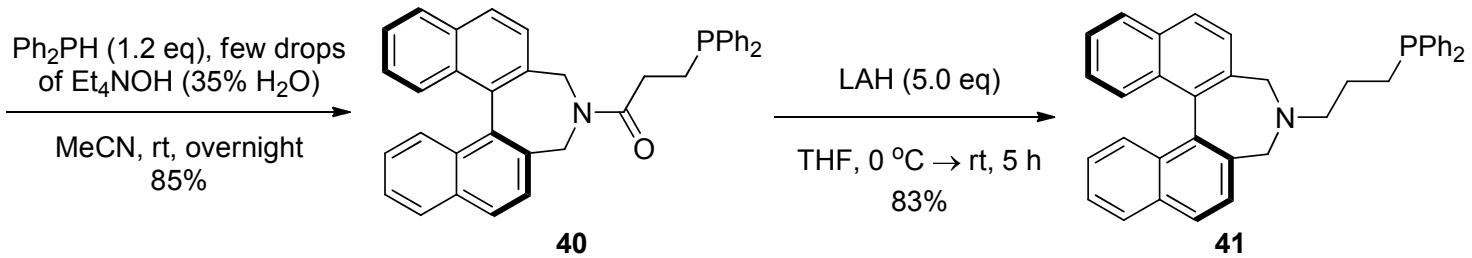

Encouraged by a slight improvement in enantioselectivity, we considered modifying the aminophosphine 41 to hopefully further enhance the enantioselectivity of the double-Michael addition. The introduction of an aryl group to binaphthyl systems at the 3 and 3' positions is commonly applied to enhance the steric bias of the molecule and increase the reaction's enantioselectivity (Figure 5) $[42,43]$. We decided to install naphthyl groups on the binaphthyl framework because of the ready availability of the requisite reagent and the medium size of the naphthyl group.

Figure 5. Elaboration of the $C_{2}$-symmetric element in the aminophosphine.
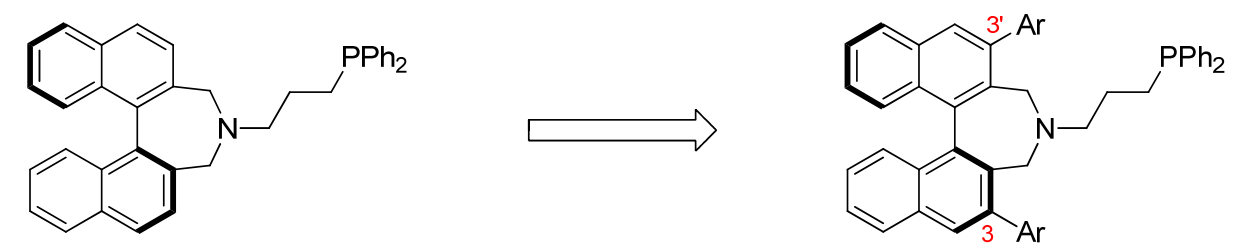

Using a reported multistep synthesis, we installed naphthyl substituents at the desired 3,3'-positions to obtain the intermediate amine 55. Subjecting the crude amine $\mathbf{5 5}$ to the aforementioned conditions for aminophosphine synthesis, we eventually isolated the amidophosphine $\mathbf{5 7}$ and the aminophosphine 58 (Scheme 7). Surprisingly, the aminophosphine 58 provided only 3\% ee, lower than the 
enantioselectivity obtained when using the unmodified aminophosphine $\mathbf{4 1}$ (Table 2, entries 12 and 13). Similarly, application of the amidophosphine 57 to the double-Michael reaction gave a yield of $88 \%$ and an enantioselectivity of only $3 \%$ ee (Table 2 , entry 26 ).

Scheme 7. Synthesis of a modified binol-derived aminophosphine.

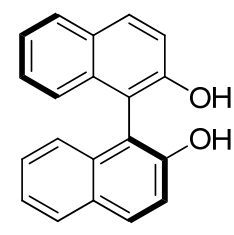

33

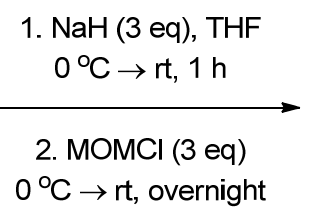
quant. yield<smiles></smiles>

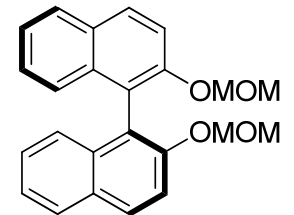

43

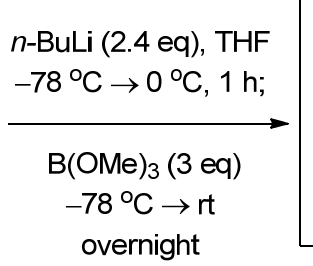

overnight

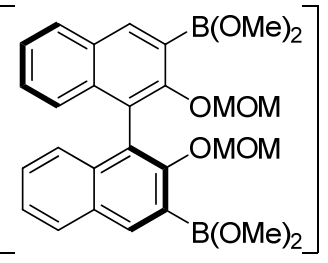

44

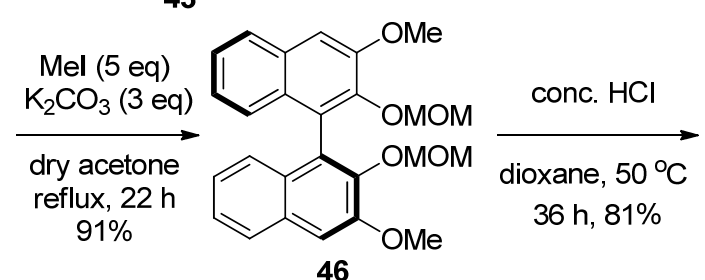<smiles>COc1cc2ccccc2c(-c2c(O)c(OC)cc3ccccc23)c1O</smiles>

47<smiles>Cc1c(O)cc2ccccc2c1-c1c(C)c(O)cc2ccccc12</smiles>

50<smiles>Cc1cc2c(-c3ccccc3)c(C)c([NH+](c3ccccc3)c3ccccc3)cc2cc1Nc1ccccc1</smiles>

52

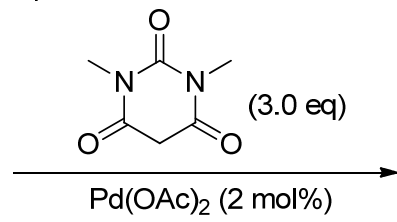

$\mathrm{PPh}_{3}(0.5 \mathrm{eq})$, degassed DCM $35^{\circ} \mathrm{C}$, overnight

54<smiles>C=CC(=O)N1Cc2c(N(c3ccccc3)c3ccccc3)cc3ccccc3c2-c2c(N(c3ccccc3)c3ccccc3)cc3ccccc3c2C1</smiles>

$\mathrm{Ph}_{2} \mathrm{PH}$ (1.2 eq) cat. $\mathrm{Bu}_{4} \mathrm{NOH}\left(37 \%\right.$ in $\left.\mathrm{H}_{2} \mathrm{O}\right)$

MeCN:DCM (3:1) rt, 6 h, $63 \%$

55

$$
\begin{gathered}
\text { Acryloyl chloride (1.2 eq) } \\
\mathrm{Et}_{3} \mathrm{~N} \text { (1.5 eq) } \\
\hline \text { dry DCM, rt, overnight } \\
70 \% \text { (2 steps) }
\end{gathered}
$$

56<smiles></smiles>

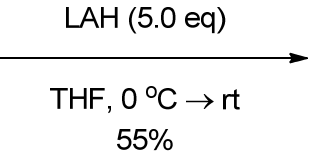<smiles>Nc1cc2ccccc2c2c1CN(CCC[PH2+]c1ccccc1)Cc1c(Nc3ccccc3P)cc3ccccc3c1-2</smiles> 


\section{Experimental}

\subsection{General}

All reactions were performed in flamed-dried round-bottom flasks under an atmosphere of Ar with dry solvents, unless otherwise noted. A glass water condenser, fitted with a rubber septum, was attached to each flask in the cases of reactions performed under reflux. A syringe pump and stainless-steel needles were used for slow addition of reagents into the reaction mixtures. Reactions were monitored through thin-layer chromatography (TLC) on $0.25-\mathrm{mm}$ SiliCycle silica gel plates, visualizing under UV light or staining with iodine, $p$-anisaldehyde, or potassium permanganate. Flash column chromatography (FCC) was performed using SiliCycle Silica-P Flash silica gel (60 ̊ pore size, $40-63 \mu \mathrm{m})$ and compressed air. Purification of phosphines was performed through quick FCC; phosphine-containing fractions were collected immediately into a flask secured under Ar. Organic solvents were evaporated in rotary evaporators under reduced pressure; the flasks were refilled with Ar when isolating phosphines. Phosphine products were stored under Ar at all times.

\subsection{Materials and Reagents}

Reagents were used as received from commercial sources, unless otherwise noted. Acryloyl chloride and potassium phosphate tribasic n-hydrate were purchased from Fluka. Tetraethylammonium hydroxide $(37 \% \mathrm{w} / \mathrm{w}$, aqueous solution), trifluoroacetic anhydride, $N, N$-dimethylbarbituric acid, methyl iodide, and $(R)-(+)-1$-phenylethylamine 1 were purchased from Alfa Aesar. Bromoacetyl bromide, lithium aluminum hydride (LAH), potassium diphenylphosphide $(0.5 \mathrm{M}$ in THF), methylmagnesium bromide (3.0 $\mathrm{M}$ in diethyl ether), hydrogen peroxide (30-32 wt \%, solution in water), $n$-butyllithium (1.6 $\mathrm{M}$ in hexanes), sodium hydride (60\% dispersion in mineral oil), methoxymethyl chloride, methyl magnesium iodide (3.0 $\mathrm{M}$ in diethyl ether), azobisisobutyronitrile (AIBN), boron tribromide, allylamine, and L-proline (11) were purchased from Aldrich. Trimethyl borate, ethyl formate, and $\mathrm{NiCl}_{2}(\mathrm{dppp})$ were purchased from Acros Organics. Palladium(II) acetate was purchased from Strem Chemicals. 2-Naphthaleneboronic acid and $(S)$-(-)-1,1'-bi-2-naphthol (33) were purchased from Combi-Blocks. Trifluoromethanesulfonic anhydride was purchased from Oakwood. Phenylmagnesium bromide was freshly prepared before use. $N$-Bromosuccinimide was recrystallized from distilled water. TMSOTf was prepared using a published procedure [44,45]. Diphenylphosphine was prepared and purified using published procedures [46,47]. Allylamine was redistilled prior to use. Acetonitrile $(\mathrm{MeCN})$, dichloromethane (DCM), and triethylamine (TEA) were distilled from $\mathrm{CaH}_{2}$ under $\mathrm{Ar}$ atmosphere. Tetrahydrofuran (THF) and diethyl ether $\left(\mathrm{Et}_{2} \mathrm{O}\right)$ were distilled from $\mathrm{Na}$ and benzophenone under $\mathrm{Ar}$ atmosphere. Dry $\mathrm{MeCN}$ and dry DCM were deoxygenated using three freeze/pump/thaw degassing cycles.

\subsection{Instrumentation}

IR spectra were recorded using a Perkin-Elmer Paragon 1000 FTIR spectrometer. NMR spectra were recorded using Bruker Avance-500, ARX-500, or Avance-300 instruments, calibrated to signals from the solvent as an internal reference $\left[7.26\left(\right.\right.$ residual $\left.\mathrm{CHCl}_{3}\right)$ and $77.00\left(\mathrm{CDCl}_{3}\right)$ ppm for ${ }^{1} \mathrm{H}$ and 
${ }^{13} \mathrm{C}-\mathrm{NMR}$ spectra, respectively]. Data for ${ }^{1} \mathrm{H}-\mathrm{NMR}$ spectra are reported in terms of chemical shift $(\delta, \mathrm{ppm})$, multiplicity, coupling constant $(\mathrm{Hz})$, and integration. Data for ${ }^{13} \mathrm{C}-\mathrm{NMR}$ spectra are reported in terms of chemical shift $(\delta, \mathrm{ppm})$, multiplicity, and coupling constants $(\mathrm{Hz})$ in the case of $J_{\mathrm{CP}}$ coupling. The following abbreviations are used to denote multiplicities: $\mathrm{s}=$ singlet; $\mathrm{d}=$ doublet; $\mathrm{t}=$ triplet; $\mathrm{q}=$ quartet; $\mathrm{qi}=$ quintet; $\mathrm{m}=$ multiplet; $\mathrm{br}=$ broad; app = apparent. Mass spectra were analyzed using instrument-supplied software. Gas chromatography/mass spectrometry (GC-MS) data were obtained using an Agilent 6890-5975 GC-MS system equipped with an autosampler and an HP5 column; samples were dissolved in DCM.

\subsection{Procedures for Syntheses of Amidophosphines and Aminophosphines}

The amine 2 [48] and the acrylamide 8 [49] in Scheme 3 were prepared following reported procedures. Compounds 12 [50], 13 [51], 14 [52], 20 [53], 21 [54], 22, 23, 25 [55], and 24 [56] in Scheme 4 provided spectral data matching those reported in the literature. Compounds 26, 27 [57], and $\mathbf{2 8}$ [58] in Scheme 5 were prepared following reported procedures. Compounds 34-38 and 43-55 were prepared following published procedures [43].

(R)-N-Methyl-N-(1-phenylethyl)acrylamide (3). The amine 2 (676 mg, $5 \mathrm{mmol})$ and dry DCM (20 $\mathrm{mL})$ were placed in a flame-dried flask containing a stirrer bar. $\mathrm{Et}_{3} \mathrm{~N}$ (1.5 equiv.) was added to the solution and then the reaction mixture was cooled to $0{ }^{\circ} \mathrm{C}$. Acryloyl chloride (1.2 equiv.) was added and then the mixture was stirred at room temperature overnight under Ar. The reaction was quenched through the addition of aqueous ammonium chloride; the mixture was extracted with DCM $(2 \times 10 \mathrm{~mL})$ and the organic phases combined, dried $\left(\mathrm{Na}_{2} \mathrm{SO}_{4}\right)$, and concentrated. The residue was purified through column chromatography $\left(\mathrm{SiO}_{2} ; 30 \%\right.$ EtOAc/Hex) to afford a pale yellow oil $3(842.1 \mathrm{mg}, 89 \%)$. ${ }^{1} \mathrm{H}-\mathrm{NMR}\left(300 \mathrm{MHz}, \mathrm{CDCl}_{3}\right) \delta$ (both rotamers) 7.28 (br s, 5H), 6.71-6.52 (m, 1H), 6.39-6.28 (m, 1H), $6.09(\mathrm{q}, J=6.9 \mathrm{~Hz}, 0.6 \mathrm{H}), 5.69(\operatorname{app~d}, J=8.7 \mathrm{~Hz}, 1 \mathrm{H}), 5.23(\mathrm{q}, J=6.0 \mathrm{~Hz}, 0.4 \mathrm{H}), 2.69(\mathrm{~s}, 1 \mathrm{H}), 1.58$ $(\mathrm{d}, J=6.0 \mathrm{~Hz}, 1 \mathrm{H}), 1.48(\mathrm{~d}, J=6.9 \mathrm{~Hz}, 2 \mathrm{H}) ;{ }^{13} \mathrm{C}-\mathrm{NMR}\left(75 \mathrm{MHz}, \mathrm{CDCl}_{3}\right) \delta$ (both rotamers) 167.2, $166.4,140.4,140.2,128.7,128.5,128.2$, 128.1, 127.6, 127.3, 126.5, 54.9, 50.6, 29.6, 28.1, 17.6, 15.5.

(R)-3-(Diphenylphosphino)-N-methyl-N-(1-phenylethyl)propanamide (4). The acrylamide 3 (568 $\mathrm{mg}$, $3 \mathrm{mmol})$ and $\mathrm{Ph}_{2} \mathrm{PH}(783 \mu \mathrm{L}, 4.5 \mathrm{mmol})$ were placed in a flask containing deoxygenated $\mathrm{MeCN}$ $(15 \mathrm{~mL})$. Aqueous $1 \mathrm{~N} \mathrm{NaOH}$ (13 drops) was added and then the mixture was heated under reflux overnight. After cooling, the reaction mixture was washed with water, dried $\left(\mathrm{Na}_{2} \mathrm{SO}_{4}\right)$, and concentrated. The residue was purified through column chromatography $\left(\mathrm{SiO}_{2} ; 30 \% \mathrm{EtOAc} / \mathrm{Hex}\right)$ to afford a colorless oil 4 (788.4 mg, 70\%). ${ }^{1} \mathrm{H}-\mathrm{NMR}\left(500 \mathrm{MHz}, \mathrm{CDCl}_{3}\right) \delta$ (both rotamers) 7.52 (br s, 5H), 7.38 (br s, 9H), 7.3 (br s, 4H), 7.18 (br s, 0.8H), 6.13 (q, $J=7.3 \mathrm{~Hz}, 0.7 \mathrm{H}$ ), 4.99 (q, $J=7.3 \mathrm{~Hz}$, $0.3 \mathrm{H}), 2.73$ (br s, 1H), 2.57 (br s, 3H), 2.53-2.48 (m, 4H), $1.56(\mathrm{~d}, J=7.2 \mathrm{~Hz}, 1 \mathrm{H}), 1.51$ (d, $J=7.2 \mathrm{~Hz}$, $3 \mathrm{H}) ;{ }^{13} \mathrm{C}-\mathrm{NMR}\left(125 \mathrm{MHz}, \mathrm{CDCl}_{3}\right) \delta 172.1(\mathrm{~d}, J=14.4 \mathrm{~Hz}), 140.5,138.2,138.1,138.05,138.00,132.7$ $(\mathrm{d}, J=6.5 \mathrm{~Hz}), 132.6(\mathrm{~d}, J=6.5 \mathrm{~Hz}), 128.60,128.58,128.4,128.35,128.3,127.2,127.1,50.3,30.2(\mathrm{~d}$, $J=20.5 \mathrm{~Hz}), 29.2,23.0(\mathrm{~d}, J=10.9 \mathrm{~Hz}), 15.5$ (rotamer) $172.1(\mathrm{~d}, J=14.4 \mathrm{~Hz}), 140.1,138.3,138.2$, 138.0, 137.9, 132.6, 132.5, 127.3, 126.2, 54.4, 29.6 (d, $J=20.5 \mathrm{~Hz}), 28.0,23.4$ (d, $J=10.9 \mathrm{~Hz}), 17.6$; ${ }^{31} \mathrm{P}-\mathrm{NMR}\left(202 \mathrm{MHz}, \mathrm{CDCl}_{3}\right) \delta-14.0$, (rotamer) -14.2 . 
(R)-3-(Diphenylphosphino)-N-methyl-N-(1-phenylethyl)propan-1-amine (5). A solution of the amidophosphine 4 (750.8 $\mathrm{mg}, 2 \mathrm{mmol})$ in dry THF $(10 \mathrm{~mL})$ was cannulated into a slurry of LAH $(379.5 \mathrm{mg}, 10 \mathrm{mmol})$ in dry $\mathrm{THF}(10 \mathrm{~mL})$ at $0{ }^{\circ} \mathrm{C}$. The mixture was then stirred at room temperature overnight before being cooled at $0{ }^{\circ} \mathrm{C}$ and having the reaction quenched through slow addition of $1 \mathrm{~N}$ $\mathrm{NaOH}(5 \mathrm{~mL}, 5 \mathrm{mmol})$. The reaction mixture was dried with $\mathrm{Na}_{2} \mathrm{SO}_{4}$ (vigorous stirring for $20 \mathrm{~min}$ ), then filtered through Celite and washed with $\mathrm{Et}_{2} \mathrm{O}(3 \times 10 \mathrm{~mL})$. After concentrating the filtrate, the residue was purified through column chromatography $\left(\mathrm{SiO}_{2} ; 3 \% \mathrm{Et}_{3} \mathrm{~N}\right.$ in $\left.10 \% \mathrm{EtOAc} / \mathrm{Hex}\right)$ to afford a colorless oil 5 (585.5 mg, 81\%). ${ }^{1} \mathrm{H}-\mathrm{NMR}\left(500 \mathrm{MHz}, \mathrm{CDCl}_{3}\right) \delta$ 7.46-7.42 (m, 5H), 7.36-7.32 (m, $10 \mathrm{H}), 3.57$ (q, $J=6.7 \mathrm{~Hz}, 1 \mathrm{H}), 2.56-2.50(\mathrm{~m}, 1 \mathrm{H}), 2.42-2.37(\mathrm{~m}, 1 \mathrm{H}), 2.17(\mathrm{~s}, 3 \mathrm{H}), 2.10-1.98(\mathrm{~m}$, 2H), $1.66-1.58(\mathrm{~m}, 2 \mathrm{H}), 1.37(\mathrm{~d}, J=6.7 \mathrm{~Hz}, 3 \mathrm{H}) ;{ }^{13} \mathrm{C}-\mathrm{NMR}\left(125 \mathrm{MHz}, \mathrm{CDCl}_{3}\right) \delta 143.9,138.93(\mathrm{~d}$, $J=13.3 \mathrm{~Hz}), 138.87$ (d, $J=13.3 \mathrm{~Hz}), 132.7$ (d, $J=4.4 \mathrm{~Hz}), 132.6$ (d, $J=4.4 \mathrm{~Hz}), 128.4,128.3,128.2$, 128.0, 127.6, 126.6, 63.1, 55.2 (d, $J=13.5 \mathrm{~Hz}), 38.3,25.5$ (d, $J=11.0 \mathrm{~Hz}), 23.5$ (d, $J=16.0 \mathrm{~Hz}), 18.3$; ${ }^{31} \mathrm{P}-\mathrm{NMR}\left(202 \mathrm{MHz}, \mathrm{CDCl}_{3}\right) \delta-15.1$; GCMS (EI+) calcd for $\left[\mathrm{C}_{9} \mathrm{H}_{4} \mathrm{Cl}_{2} \mathrm{O}\right]: \mathrm{m} / z$ 361.2, found 361.3 .

(R)-2-(Diphenylphosphino)-N-methyl-N-(1-phenylethyl)acetamide (6). The amine 2 (676 $\mathrm{mg}, 5 \mathrm{mmol})$ was added to a solution of DMAP $(733 \mathrm{mg}, 6 \mathrm{mmol})$ in dry THF $(50 \mathrm{~mL})$. The mixture was cooled to $0{ }^{\circ} \mathrm{C}$ and then bromoacetyl bromide $(1.21 \mathrm{~g}, 6 \mathrm{mmol})$ in dry THF $(20 \mathrm{~mL})$ was added slowly. After stirring at room temperature for $2 \mathrm{~h}$, the mixture was filtered through a short pad of silica gel, which was washed with $\mathrm{Et}_{2} \mathrm{O}$ until the product had completely eluted out. The filtrate was concentrated and then replenished with dry THF $(50 \mathrm{~mL})$. The mixture was cooled to $-78{ }^{\circ} \mathrm{C}$ and then $\mathrm{Ph}_{2} \mathrm{PK}(0.5 \mathrm{~N}$ in THF, $7.5 \mathrm{mmol}, 15 \mathrm{~mL}$ ) was added slowly. The mixture was stirred overnight at room temperature and then it was quenched (saturated $\mathrm{NH}_{4} \mathrm{Cl}$ ), washed (water), dried $\left(\mathrm{Na}_{2} \mathrm{SO}_{4}\right)$, and concentrated. The residue was purified through column chromatography $\left(\mathrm{SiO}_{2}\right.$; gradient $20-50 \%$ EtOAc/Hex $)$ to afford a colorless oil $6(513 \mathrm{mg}, 40 \%)$. ${ }^{1} \mathrm{H}-\mathrm{NMR}\left(300 \mathrm{MHz}, \mathrm{CDCl}_{3}\right) \delta$ (both rotamers) 7.54-7.47 (m, 6H), $7.35-7.19(\mathrm{~m}, 15 \mathrm{H}), 6.03(\mathrm{q}, J=7.1 \mathrm{~Hz}, 1 \mathrm{H}), 5.33(\mathrm{q}, J=7.1 \mathrm{~Hz}, 0.4 \mathrm{H}), 3.32(\mathrm{~s}, 0.8 \mathrm{H}), 3.23(\mathrm{~s}, 2 \mathrm{H})$, $2.67(\mathrm{~s}, 1.2 \mathrm{H}), 2.65(\mathrm{~s}, 3 \mathrm{H}), 1.56(\mathrm{~d}, J=7.0 \mathrm{~Hz}, 1.2 \mathrm{H}), 1.42(\mathrm{~d}, J=7.0 \mathrm{~Hz}, 3 \mathrm{H}) ;{ }^{13} \mathrm{C}-\mathrm{NMR}(75 \mathrm{MHz}$, $\left.\mathrm{CDCl}_{3}\right) \delta$ (both rotamers) $169.84(\mathrm{~d}, J=7.8 \mathrm{~Hz}), 169.8(\mathrm{~d}, J=7.8 \mathrm{~Hz}), 140.6,140.3,138.2(\mathrm{~d}, J=14.3 \mathrm{~Hz})$, $138.0(\mathrm{~d}, J=14.3 \mathrm{~Hz}), 133.0,132.7,128.9,128.7,128.6,128.5,128.4,127.5,127.3,127.2,126.5$, 50.5, 35.7, 35.4, 30.4, 30.3, 28.2, 17.9, 15.5; ${ }^{31} \mathrm{P}-\mathrm{NMR}\left(121 \mathrm{MHz}, \mathrm{CDCl}_{3}\right) \delta-18.8$, (rotamer) -18.7.

(R)-2-(Diphenylphosphino)-N-methyl-N-(1-phenylethyl)ethanamine (7). Using the procedure described for the synthesis of the aminophosphine 5, the aminophosphine 7 (67\%) was obtained as a colorless oil. ${ }^{1} \mathrm{H}-\mathrm{NMR}\left(300 \mathrm{MHz}, \mathrm{CDCl}_{3}\right) \delta$ (both rotamers) 7.40-7.34 (m, 4H), 7.33-7.19 (m, 11H), 3.56 (q, $J=6.8 \mathrm{~Hz}, 1 \mathrm{H}), 2.67-2.43(\mathrm{~m}, 2 \mathrm{H}), 2.31-2.16(\mathrm{~m}, 5 \mathrm{H}), 1.30(\mathrm{~d}, J=6.8 \mathrm{~Hz}, 3 \mathrm{H}) ;{ }^{13} \mathrm{C}-\mathrm{NMR}(75 \mathrm{MHz}$, $\left.\mathrm{CDCl}_{3}\right) \delta 144.0,138.7(\mathrm{~d}, J=12.6 \mathrm{~Hz}), 138.6(\mathrm{~d}, J=12.6 \mathrm{~Hz}), 132.8(\mathrm{~d}, J=1.9 \mathrm{~Hz}), 132.5(\mathrm{~d}$, $J=1.9 \mathrm{~Hz}), 128.5,128.48,128.44,128.35,128.2,127.6,126.8,63.1,51.0(\mathrm{~d}, J=22.9 \mathrm{~Hz}), 38.5,25.9$ $(\mathrm{d}, J=12.0 \mathrm{~Hz}), 18.9 ;{ }^{31} \mathrm{P}-\mathrm{NMR}\left(121 \mathrm{MHz}, \mathrm{CDCl}_{3}\right) \delta-19.9$.

(R)-3-(Diphenylphosphino)-N-(1-phenylethyl)propanamide (9). Using the procedure described for the synthesis of the aminophosphine 10, but stopping at the first step, the amidophosphine 9 was obtained as a colorless oil. ${ }^{1} \mathrm{H}-\mathrm{NMR}\left(300 \mathrm{MHz}, \mathrm{CDCl}_{3}\right) \delta 7.45-7.39(\mathrm{~m}, 4 \mathrm{H}), 7.36-7.27(\mathrm{~m}, 11 \mathrm{H}), 5.64(\mathrm{~d}$, $J=7.3 \mathrm{~Hz}, 1 \mathrm{H}), 5.10$ (app qi, $J=7.3 \mathrm{~Hz}, 1 \mathrm{H}), 2.43-2.36(\mathrm{~m}, 2 \mathrm{H}), 2.29-2.19$ (m, 2H), 1.46 (d, 
$J=6.9 \mathrm{~Hz}, 3 \mathrm{H}) ;{ }^{13} \mathrm{C}-\mathrm{NMR}\left(75 \mathrm{MHz}, \mathrm{CDCl}_{3}\right) \delta 171.2(\mathrm{~d}, J=12.8 \mathrm{~Hz}), 143.1,137.9(\mathrm{~d}, J=12.6 \mathrm{~Hz})$, 132.9, 132.6, 128.7 (d, $J=7.1 \mathrm{~Hz}), 128.5$ (d, $J=6.6 \mathrm{~Hz}), 127.4,126.2,48.9,32.9$ (d, $J=18.3 \mathrm{~Hz})$, $23.4(\mathrm{~d}, J=12.1 \mathrm{~Hz}), 21.7 ;{ }^{31} \mathrm{P}-\mathrm{NMR}\left(121 \mathrm{MHz}, \mathrm{CDCl}_{3}\right) \delta-15.4$.

(R)-3-(Diphenylphosphino)-N-(1-phenylethyl)propan-1-amine (10). $\mathrm{Ph}_{2} \mathrm{PH}(0.7 \mathrm{~mL}, 4 \mathrm{mmol})$ was added to a solution of the acrylamide $8(350 \mathrm{mg}, 2 \mathrm{mmol})$ in dry $\mathrm{MeCN}(10 \mathrm{~mL}) . \mathrm{Et}_{4} \mathrm{NOH} \cdot \mathrm{H}_{2} \mathrm{O}(37 \%$ aqueous solution, $0.5 \mathrm{~mL}$ ) was added and then the mixture was stirred at room temperature overnight before being concentrated. The residue was dissolved in DCM $(20 \mathrm{~mL})$, washed with water $(5 \mathrm{~mL})$, dried $\left(\mathrm{Na}_{2} \mathrm{SO}_{4}\right)$, and concentrated. The residue was dissolved in dry THF $(5 \mathrm{~mL})$ and then cannulated into a flask containing a slurry of LAH $(380 \mathrm{mg}, 10 \mathrm{mmol})$ in dry THF $(10 \mathrm{~mL})$ under Argon. After overnight stirring at room temperature, the reaction mixture was cooled to $0{ }^{\circ} \mathrm{C}$ and $1 \mathrm{~N} \mathrm{NaOH}(4 \mathrm{~mL}$, $4 \mathrm{mmol}$ ) was added to quench the reaction. $\mathrm{Na}_{2} \mathrm{SO}_{4}$ was added and the mixture was stirred vigorously for $20 \mathrm{~min}$, then filtered through Celite and washed with $\mathrm{Et}_{2} \mathrm{O}(3 \times 10 \mathrm{~mL})$. The filtrate was concentrated under vacuo and the residue was purified through column chromatography $\left(\mathrm{SiO}_{2} ; 5 \%\right.$ $\mathrm{Et}_{3} \mathrm{~N}$ in $\left.30 \% \mathrm{EtOAc} / \mathrm{Hex}\right)$ to afford a colorless oil 10 (569.8 mg, 82\%). ${ }^{1} \mathrm{H}-\mathrm{NMR}\left(500 \mathrm{MHz}, \mathrm{CDCl}_{3}\right)$ $\delta 7.48-7.44(\mathrm{~m}, 4 \mathrm{H}), 7.39-7.27(\mathrm{~m}, 11 \mathrm{H}), 3.77(\mathrm{q}, J=6.5 \mathrm{~Hz}, 1 \mathrm{H}), 2.67-2.55(\mathrm{~m}, 2 \mathrm{H}), 2.15-2.03(\mathrm{~m}$, 2H), $1.72-1.57(\mathrm{~m}, 2 \mathrm{H}), 1.38(\mathrm{~d}, J=6.5 \mathrm{~Hz}, 3 \mathrm{H})$; ${ }^{13} \mathrm{C}-\mathrm{NMR}\left(125 \mathrm{MHz}, \mathrm{CDCl}_{3}\right) \delta 145.6,138.7(\mathrm{~d}$, $J=12.3 \mathrm{~Hz}), 138.6(\mathrm{~d}, J=12.3 \mathrm{~Hz}), 132.7$ (d, $J=4.2 \mathrm{~Hz}), 132.5(\mathrm{~d}, J=4.2 \mathrm{~Hz}), 128.4,128.3,128.2$, 126.7, 126.4, 58.0, $48.7(\mathrm{~d}, J=13.6 \mathrm{~Hz}), 26.5(\mathrm{~d}, J=16.0 \mathrm{~Hz}), 25.6(\mathrm{~d}, J=11.5 \mathrm{~Hz}), 24.2 ;{ }^{31} \mathrm{P}-\mathrm{NMR}$ $\left(202 \mathrm{MHz}, \mathrm{CDCl}_{3}\right) \delta-14.6$.

(S)-1-(2-((Benzyloxy)methyl)pyrrolidin-1-yl)prop-2-en-1-one (15). TFA (25 mL) was added to a solution of $14(1.19 \mathrm{~g}, 6.6 \mathrm{mmol})$ in DCM $(25 \mathrm{~mL})$ and then the mixture was stirred for $5 \mathrm{~h}$ at room temperature. The solution was concentrated and the residue poured into a premixed solid comprising $\mathrm{NaHCO}_{3}$ and a few pieces of ice; the aqueous phase was extracted with $\mathrm{DCM}$, dried $\left(\mathrm{Na}_{2} \mathrm{SO}_{4}\right)$, and concentrated. The residue was dissolved in dry DCM $(50 \mathrm{~mL})$; TEA $(1.4 \mathrm{~mL}, 10 \mathrm{mmol})$ was added to the solution, which was then cooled to $0{ }^{\circ} \mathrm{C}$. Acryloyl chloride $(0.66 \mathrm{~mL}, 8.2 \mathrm{mmol})$ was added and then the mixture was stirred at room temperature overnight before being filtered through a short pad of silica gel and washed with DCM $(4 \times)$ until the product had eluted completely. The filtrate was concentrated and the residue purified through column chromatography $\left(\mathrm{SiO}_{2} ; 30 \% \mathrm{EtOAc} / \mathrm{Hex}\right)$ to afford $15(1.44 \mathrm{~g}, 89 \%)$ as a pale yellow oil. ${ }^{1} \mathrm{H}-\mathrm{NMR}\left(300 \mathrm{MHz}, \mathrm{CDCl}_{3}\right) \delta$ (both rotamers) 7.37-7.28 $(\mathrm{m}, 5 \mathrm{H}), 6.56-6.32(\mathrm{~m}, 2 \mathrm{H}), 5.68-5.59(\mathrm{~m}, 1 \mathrm{H}), 4.53(\mathrm{~s}, 0.5 \mathrm{H}), 4.51(\mathrm{~s}, 1.5 \mathrm{H}), 4.42-4.36(\mathrm{~m}, 0.5 \mathrm{H})$, $4.18-4.11(\mathrm{~m}, 0.5 \mathrm{H}), 3.70(\mathrm{dd}, J=9.4,3.1 \mathrm{~Hz}, 0.5 \mathrm{H}), 3.61-3.32(\mathrm{~m}, 3.5 \mathrm{H}), 2.12-1.97(\mathrm{~m}, 2 \mathrm{H})$, 1.94-1.84 (m, 2H); ${ }^{13} \mathrm{C}-\mathrm{NMR}\left(75 \mathrm{MHz}, \mathrm{CDCl}_{3}\right) \delta$ (both rotamers) 164.9, 164.7, 138.6, 137.8, 129.1, $128.8,128.5,128.3,127.8,127.6,127.5,127.4,73.4,73.2,71.7,70.1,56.9,56.8,47.4,46.0,29.0$, $27.5,24.2,21.9$.

(S)-1-(2-((Benzyloxy)methyl)pyrrolidin-1-yl)-3-(diphenylphosphino)propan-1-one (16). $\mathrm{Ph}_{2} \mathrm{PH}(1.2 \mathrm{~mL}$, $6.9 \mathrm{mmol})$ and $1 \mathrm{M} \mathrm{NaOH}$ (10-15 drops) were added to a solution of $\mathbf{1 5}$ (1.35 g, $5.5 \mathrm{mmol})$ in dry $\mathrm{MeCN}(10 \mathrm{~mL})$ and dry DCM $(10 \mathrm{~mL})$. The mixture was stirred at room temperature overnight before being concentrated and purified through column chromatography $\left(\mathrm{SiO}_{2} ; 50 \%\right.$ EtOAc/Hex $)$ to afford 16 $(1.42 \mathrm{~g}, 60 \%)$ as a colorless oil. ${ }^{1} \mathrm{H}-\mathrm{NMR}\left(300 \mathrm{MHz}, \mathrm{CDCl}_{3}\right) \delta$ (both rotamers) $7.47-7.40(\mathrm{~m}, 4 \mathrm{H})$, 
7.36-7.23 (m, 11H), $4.54(\mathrm{~d}, J=12.0 \mathrm{~Hz}, 0.7 \mathrm{H}), 4.47(\mathrm{~d}, J=12.0 \mathrm{~Hz}, 0.7 \mathrm{H}), 4.41(\mathrm{~d}, J=12.0 \mathrm{~Hz}$, $0.3 \mathrm{H}), 4.35(\mathrm{~d}, J=12.0 \mathrm{~Hz}, 0.3 \mathrm{H}), 4.30-4.23(\mathrm{~m}, 0.7 \mathrm{H}), 3.93-3.85(\mathrm{~m}, 0.3 \mathrm{H}), 3.65(\mathrm{~d}, J=3.3 \mathrm{~Hz}$, $0.3 \mathrm{H}), 3.62(\mathrm{~d}, J=3.3 \mathrm{~Hz}, 0.7 \mathrm{H}), 3.50(\mathrm{~d}, J=6.88 \mathrm{~Hz}, 0.6 \mathrm{H}), 3.47(\mathrm{~d}, J=6.88 \mathrm{~Hz}, 0.4 \mathrm{H}), 3.31-3.18$ (m, 2H), 2.52-2.27 (m, 4H), 2.05-1.82 (m, 4H); ${ }^{13} \mathrm{C}-\mathrm{NMR}\left(75 \mathrm{MHz}, \mathrm{CDCl}_{3}\right) \delta$ (both rotamers) 171.1 (d, $J=14.5 \mathrm{~Hz}), 138.6,138.4(\mathrm{~d}, J=16.7), 138.2$ (d, $J=16.7 \mathrm{~Hz}), 132.9,132.9$ (d, $J=3.8 \mathrm{~Hz}), 132.7$, $132.6(\mathrm{~d}, J=3.8 \mathrm{~Hz}), 128.72,128.70,128.53,128.5,128.4,128.3,127.54,127.5,73.3,73.2,71.4$, 70.1, 56.9, 56.7, 47.2, 47.8, 31.4, 31.2, 28.8, 27.6, 24.1, 23.4, 22.8, 22.7, 21.9; ${ }^{31} \mathrm{P}-\mathrm{NMR}(121 \mathrm{MHz}$, $\left.\mathrm{CDCl}_{3}\right) \delta-15.2$, (rotamer) -15.3 .

(S)-2-((Benzyloxy)methyl)-1-(3-(diphenylphosphino)propyl)pyrrolidine (17). Using the procedure described for the synthesis of the aminophosphine 5, the aminophosphine 17 (76\%) was obtained as a colorless oil. ${ }^{1} \mathrm{H}-\mathrm{NMR}\left(300 \mathrm{MHz}, \mathrm{CDCl}_{3}\right) \delta$ 7.44-7.40 (m, 4H), 7.33 (br s, 11H), $4.52(\mathrm{~s}, 2 \mathrm{H})$, 3.50-3.46 (m, 1H), 3.37-3.13 (m, 1H), 3.05-3.03 (m, 1H), 2.97-2.91 (m, 1H), 2.64-2.62 (m, 1H), 2.41-2.35 (m, 1H), 2.14-2.09 (m, 2H), 2.05-1.98 (m, 1H), 1.95-1.84 (m, 1H), 1.72-1.60 (m, 5H); ${ }^{13} \mathrm{C}-\mathrm{NMR}\left(75 \mathrm{MHz}, \mathrm{CDCl}_{3}\right) \delta 139.1(\mathrm{~d}, J=20.1 \mathrm{~Hz}), 138.9(\mathrm{~d}, J=19.9 \mathrm{~Hz}), 138.6,132.9(\mathrm{~d}, J=15.8 \mathrm{~Hz})$, $132.6(\mathrm{~d}, J=15.5 \mathrm{~Hz}), 128.5,128.4,128.3,127.7,127.5,74.0,73.3,63.6,56.8$ (d, $J=13.8 \mathrm{~Hz}), 54.4$, 28.6, $25.9(\mathrm{~d}, J=11.3 \mathrm{~Hz}), 25.4(\mathrm{~d}, J=16.1 \mathrm{~Hz}), 23.0 ;{ }^{31} \mathrm{P}-\mathrm{NMR}\left(121 \mathrm{MHz}, \mathrm{CDCl}_{3}\right) \delta-15.9$.

(S)-3-(Diphenylphosphino)-1-(2-(hydroxymethyl)pyrrolidin-1-yl)propan-1-one (18). Using the procedures described for the syntheses of 3 and 4, 18 was obtained as a colorless oil. IR (film) $v_{\max }$ $3385,3051,2951,2875,1621,1434,1313,1188,1052 \mathrm{~cm}^{-1} ;{ }^{1} \mathrm{H}-\mathrm{NMR}\left(500 \mathrm{MHz}, \mathrm{CDCl}_{3}\right) \delta 7.46-7.42$ (m, 4H), 7.35-7.32 (m, 6H), 4.97 (br s, 1H), 4.19-4.14 (m, 1H), 3.65-3.64 (m, 1H), 3.55-3.51 (m, $1 \mathrm{H}), 3.37-3.28(\mathrm{~m}, 2 \mathrm{H}), 2.42-2.35(\mathrm{~m}, 4 \mathrm{H}), 2.01-1.95(\mathrm{~m}, 1 \mathrm{H}), 1.91-1.83(\mathrm{~m}, 1 \mathrm{H}), 1.83-1.75(\mathrm{~m}$, 1H), $1.59-1.52(\mathrm{~m}, 1 \mathrm{H}) ;{ }^{13} \mathrm{C}-\mathrm{NMR}\left(125 \mathrm{MHz}, \mathrm{CDCl}_{3}\right) \delta 173.4(\mathrm{~d}, J=14.3 \mathrm{~Hz}), 137.8(\mathrm{~d}, J=12.1 \mathrm{~Hz})$, $137.8(\mathrm{~d}, J=12.1 \mathrm{~Hz}), 132.7,132.5,128.7,128.4(\mathrm{~d}, J=6.5 \mathrm{~Hz}), 67.2,61.2,47.8,31.3$ (d, $J=20.3 \mathrm{~Hz})$, 28.1, 24.2, 22.7 (d, $J=10.6 \mathrm{~Hz}) ;{ }^{31} \mathrm{P}-\mathrm{NMR}\left(202 \mathrm{MHz}, \mathrm{CDCl}_{3}\right) \delta-14.3$.

(S)-(1-(3-(Diphenylphosphino)propyl)pyrrolidin-2-yl)methanol (19). Using the procedure described for the synthesis of the aminophosphine 5, the aminophosphine 19 (76\%) was obtained as a colorless oil. ${ }^{1} \mathrm{H}-\mathrm{NMR}\left(500 \mathrm{MHz}, \mathrm{CDCl}_{3}\right) \delta 7.44-7.39(\mathrm{~m}, 4 \mathrm{H}), 7.32$ (br s, 6H), $3.62(\mathrm{dd}, J=10.5,3.2 \mathrm{~Hz}, 1 \mathrm{H})$, $3.37(\mathrm{~d}, J=10.5 \mathrm{~Hz}, 1 \mathrm{H}), 3.05-3.01(\mathrm{~m}, 1 \mathrm{H}), 2.85-2.79(\mathrm{~m}, 1 \mathrm{H}), 2.54-2.51(\mathrm{~m}, 1 \mathrm{H}), 2.36-2.31(\mathrm{~m}$, $1 \mathrm{H}), 2.17-2.11(\mathrm{~m}, 2 \mathrm{H}), 2.05-1.99(\mathrm{~m}, 1 \mathrm{H}), 1.88-1.81(\mathrm{~m}, 1 \mathrm{H}), 1.79-1.73(\mathrm{~m}, 1 \mathrm{H}), 1.71-1.66(\mathrm{~m}$, 2H), $1.64-1.58(\mathrm{~m}, 2 \mathrm{H}) ;{ }^{13} \mathrm{C}-\mathrm{NMR}\left(125 \mathrm{MHz}, \mathrm{CDCl}_{3}\right) \delta 138.6(\mathrm{~d}, J=21.5 \mathrm{~Hz}), 138.5(\mathrm{~d}, J=21.5 \mathrm{~Hz})$, 132.7, 132.6, 132.4, 128.5, 128.4, 128.3 (d, $J=6.9 \mathrm{~Hz}), 128.27$ (d, $J=6.9 \mathrm{~Hz}), 64.6,61.7,55.0$ (d, $J=13.1 \mathrm{~Hz}), 53.8,27.4,25.6(\mathrm{~d}, J=11.1 \mathrm{~Hz}), 25.1(\mathrm{~d}, J=15.6 \mathrm{~Hz}), 23.4 ;{ }^{31} \mathrm{P}-\mathrm{NMR}(202 \mathrm{MHz}$, $\left.\mathrm{CDCl}_{3}\right) \delta-15.4$.

(S)-1-(2-(Diphenyl((trimethylsilyl)oxy)methyl)pyrrolidin-1-yl)prop-2-en-1-one (29). Using the procedure described for the synthesis of the acrylamide 15, the acrylamide $\mathbf{2 9}(81 \%)$ was obtained as a colorless oil. ${ }^{1} \mathrm{H}-\mathrm{NMR}\left(500 \mathrm{MHz}, \mathrm{CDCl}_{3}\right) \delta$ (both rotamers) 7.47-7.25 (m, 10H), 6.81 (dd, $J=16.8$, $12.3 \mathrm{~Hz}, 0.7 \mathrm{H}), 6.29(\mathrm{dd}, J=16.8,2.0 \mathrm{~Hz}, 0.7 \mathrm{H}), 6.25(\mathrm{dd}, J=16.8,12.3 \mathrm{~Hz}, 0.3 \mathrm{H}), 6.12$ (dd, $J=16.8,2.0 \mathrm{~Hz}, 0.3 \mathrm{H}), 5.63-5.52(\mathrm{~m}, 1 \mathrm{H}), 5.39(\mathrm{dd}, J=12.3,2.0 \mathrm{~Hz}, 0.7 \mathrm{H}), 5.10(\mathrm{dd}, J=12.3$, $2.0 \mathrm{~Hz}, 0.3 \mathrm{H}), 3.77-3.76(\mathrm{~m}, 0.7 \mathrm{H}), 3.42-3.39(\mathrm{~m}, 0.3 \mathrm{H}), 3.89-3.87(\mathrm{~m}, 0.3 \mathrm{H}), 2.19-2.15(\mathrm{~m}, 0.7 \mathrm{H})$, 
2.09-2.07 (m, 0.7H), 1.92-1.88 (m, 0.3H), 1.86 (br s, 1H), 1.62-1.58 (m, 0.3H), 1.51-1.46 (m, 0.7H), $1.35-1.29(\mathrm{~m}, 0.3 \mathrm{H}), 1.20-1.14(\mathrm{~m}, 0.7 \mathrm{H}),-0.13(\mathrm{~s}, 2.7 \mathrm{H}),-0.25(\mathrm{~s}, 6.3 \mathrm{H}) ;{ }^{13} \mathrm{C}-\mathrm{NMR}(125 \mathrm{MHz}$, $\left.\mathrm{CDCl}_{3}\right) \delta$ (both rotamers) 166.01, 166.00, 144.3, 144.2, 142.3, 141.0, 130.4, 129.6, 129.3, 129.2, $128.8,128.1,127.6,127.4,127.3,127.2,127.0,126.4,125.7,84.4,65.9,62.4,48.2,46.3,28.3,27.1$, $23.8,21.8,1.8$.

(S)-3-(Diphenylphosphino)-1-(2-(hydroxydiphenylmethyl)pyrrolidin-1-yl)propan-1-one (30). Using the procedure described for the synthesis of the amidophosphine 18, the amidophosphine 30 (94\%) was obtained as a colorless oil. ${ }^{1} \mathrm{H}-\mathrm{NMR}\left(500 \mathrm{MHz}, \mathrm{CDCl}_{3}\right) \delta 7.43-7.25(\mathrm{~m}, 20 \mathrm{H}), 6.92(\mathrm{~s}, 1 \mathrm{H}), 5.16-5.13$ (m, 1H), 3.19-3.17 (m, 1H), 2.78-2.77 (m, 1H), 2.34-2.30 (m, 3H), 2.23-2.21 (m, 1H), 2.04-2.02 (m, 1H), $1.93-1.92(\mathrm{~m}, 1 \mathrm{H}), 1.50-1.43(\mathrm{~m}, 1 \mathrm{H}), 0.94-0.91(\mathrm{~m}, 1 \mathrm{H}) ;{ }^{13} \mathrm{C}-\mathrm{NMR}\left(125 \mathrm{MHz}, \mathrm{CDCl}_{3}\right) \delta 174.8$ $(\mathrm{d}, J=15.0 \mathrm{~Hz}), 146.0,143.3,137.8(\mathrm{~d}, J=12.6 \mathrm{~Hz}), 132.7(\mathrm{~d}, J=11.9 \mathrm{~Hz}), 132.5(\mathrm{~d}, J=11.8 \mathrm{~Hz})$, $128.74,128.71,128.5,128.4,128.0,127.8,127.6,127.3,127.14,127.12,81.9,66.8,48.4,31.5$ (d, $J=19.9 \mathrm{~Hz}), 29.4,23.1,22.9(\mathrm{~d}, J=11.3 \mathrm{~Hz}) ;{ }^{31} \mathrm{P}-\mathrm{NMR}\left(202 \mathrm{MHz}, \mathrm{CDCl}_{3}\right) \delta-14.3$.

(S)-(1-(3-(Diphenylphosphino)propyl)pyrrolidin-2-yl)diphenylmethanol (31). Using the procedure described for the synthesis of the aminophosphine 19, the aminophosphine 31 (85\%) was obtained as a white crystalline solid. ${ }^{1} \mathrm{H}-\mathrm{NMR}\left(500 \mathrm{MHz}, \mathrm{CDCl}_{3}\right) \delta 7.63(\mathrm{~d}, J=7.9 \mathrm{~Hz}, 2 \mathrm{H}), 7.56(\mathrm{~d}, J=7.9 \mathrm{~Hz}$, 2H), 7.42-7.30 (m, 12H), $7.26(\mathrm{t}, J=7.9 \mathrm{~Hz}, 2 \mathrm{H}), 7.21-7.16(\mathrm{~m}, 2 \mathrm{H}), 4.85(\mathrm{~s}, 1 \mathrm{H}), 3.85-3.83(\mathrm{~m}, 1 \mathrm{H})$, 3.13-3.10 (m, 1H), 2.34-2.29 (m, 1H), 2.26-2.21 (m, 1H), 2.00-1.87 (m, 2H), 1.82-1.60 (m, 5H), $1.56-1.50(\mathrm{~m}, 1 \mathrm{H}), 1.39-1.31(\mathrm{~m}, 2 \mathrm{H}) ;{ }^{13} \mathrm{C}-\mathrm{NMR}\left(125 \mathrm{MHz}, \mathrm{CDCl}_{3}\right) \delta 148.0,146.4,138.7(\mathrm{~d}$, $J=16.7 \mathrm{~Hz}), 138.6(\mathrm{~d}, J=16.7 \mathrm{~Hz}), 132.7,132.5(\mathrm{~d}, J=5.0 \mathrm{~Hz}), 132.3,128.4,128.29,128.27$, 128.22, 128.18, 127.9 (d, $J=4.4 \mathrm{~Hz}), 126.0,125.6,125.5,77.8,71.0,57.4$ (d, $J=14.2 \mathrm{~Hz}), 55.1,29.4$, $25.2(\mathrm{~d}, J=10.7 \mathrm{~Hz}), 24.9$ (d, $J=15.6 \mathrm{~Hz}), 24.4 ;{ }^{31} \mathrm{P}-\mathrm{NMR}\left(202 \mathrm{MHz}, \mathrm{CDCl}_{3}\right) \delta-14.6$.

(S)-2-(Diphenyl((trimethylsilyl)oxy)methyl)-1-(3-(diphenylphosphino)propyl)pyrrolidine (32). TMSOTf $(255 \mu \mathrm{L}, 1.4 \mathrm{mmol})$ was added to a solution of the aminophosphine 31 (335.7 $\mathrm{mg}, 0.7 \mathrm{mmol})$ and TEA $(0.3 \mathrm{~mL}, 2.1 \mathrm{mmol})$ in dry $\mathrm{DCM}(5 \mathrm{~mL})$ at $0{ }^{\circ} \mathrm{C}$. The mixture was stirred overnight and then concentrated. The residue was purified through column chromatography $\left(\mathrm{SiO}_{2} ; 15 \% \mathrm{EtOAc} / \mathrm{Hex}\right)$ to afford $32(266.5 \mathrm{mg}, 69 \%)$ as a colorless oil. ${ }^{1} \mathrm{H}-\mathrm{NMR}\left(500 \mathrm{MHz}, \mathrm{CDCl}_{3}\right) \delta 7.61-7.58(\mathrm{~m}, 2 \mathrm{H})$, 7.53-7.50 (m, 2H), 7.46-7.42 (m, 4H), 7.41-7.37 (m, 6H), 7.34-7.31 (m, 3H), 7.29-7.27 (m, 3H), 3.75 $(\mathrm{dd}, J=9.7,3.2 \mathrm{~Hz}, 1 \mathrm{H}), 2.95(\mathrm{q}, J=9.7 \mathrm{~Hz}, 1 \mathrm{H}), 2.66(\mathrm{dt}, J=8.9,2.2 \mathrm{~Hz}, 1 \mathrm{H}), 2.52(\mathrm{dt}, J=11.3$, $5.6 \mathrm{~Hz}, 1 \mathrm{H}), 2.13-2.08(\mathrm{~m}, 2 \mathrm{H}), 1.94-1.86(\mathrm{~m}, 1 \mathrm{H}), 1.79-1.70(\mathrm{~m}, 2 \mathrm{H}), 1.52-1.44(\mathrm{~m}, 2 \mathrm{H}), 1.36-1.30$ $(\mathrm{m}, 1 \mathrm{H}), 0.67-0.57(\mathrm{~m}, 1 \mathrm{H}),-0.12(\mathrm{~s}, 9 \mathrm{H}) ;{ }^{13} \mathrm{C}-\mathrm{NMR}\left(125 \mathrm{MHz}, \mathrm{CDCl}_{3}\right) \delta 144.4,143.7,139.2(\mathrm{~d}$, $J=13.6 \mathrm{~Hz}), 139.0(\mathrm{~d}, J=13.6 \mathrm{~Hz}), 132.7,132.6,132.4,129.6(\mathrm{~d}, J=4.8 \mathrm{~Hz}), 128.3,128.2,128.16$, 126.74, 126.71, 84.5, 72.1, $59.0(\mathrm{~d}, J=14.5 \mathrm{~Hz}), 54.5,28.7,25.5,25.5,25.3,23.7,2.0 ;{ }^{31} \mathrm{P}-\mathrm{NMR}(202$ $\left.\mathrm{MHz}, \mathrm{CDCl}_{3}\right) \delta-14.4$.

1-(3H-Dinaphtho[2,1-c:1',2'-e]azepin-4(5H)-yl)prop-2-en-1-one (39). Using the procedure described for the synthesis of the acrylamide 29, the acrylamide $39(75 \%)$ was obtained as a light-yellow foam. ${ }^{1} \mathrm{H}-\mathrm{NMR}\left(500 \mathrm{MHz}, \mathrm{CDCl}_{3}\right) \delta 8.00-7.95(\mathrm{~m}, 4 \mathrm{H}), 7.65(\mathrm{~d}, J=8.4 \mathrm{~Hz}, 1 \mathrm{H}), 7.52-7.44(\mathrm{~m}, 5 \mathrm{H}), 7.30$ $(\mathrm{q}, J=7.0 \mathrm{~Hz}, 2 \mathrm{H}), 6.71(\mathrm{dd}, J=16.9,10.6 \mathrm{~Hz}, 1 \mathrm{H}), 6.35(\mathrm{dd}, J=16.9,1.4 \mathrm{~Hz}, 1 \mathrm{H}), 5.77(\mathrm{dd}$, $J=10.6,1.4 \mathrm{~Hz}, 1 \mathrm{H}), 5.45(\mathrm{~d}, J=13.7 \mathrm{~Hz}, 1 \mathrm{H}), 4.79(\mathrm{~d}, J=12.8 \mathrm{~Hz}, 1 \mathrm{H}), 4.01(\mathrm{~d}, J=12.8 \mathrm{~Hz}, 1 \mathrm{H})$, 
$3.60(\mathrm{~d}, J=13.7 \mathrm{~Hz}, 1 \mathrm{H}) ;{ }^{13} \mathrm{C}-\mathrm{NMR}\left(125 \mathrm{MHz}, \mathrm{CDCl}_{3}\right) \delta 164.9,135.2,134.9,133.3,133.2,132.8$, 132.0, 131.3, 131.2, 129.2, 128.6, 128.3, 128.2, 127.9, 127.7, 127.4, 127.2, 126.7, 126.1, 126.0, 125.8, 49.7, 46.5.

1-(3H-Dinaphtho[2,1-c:1',2'-e]azepin-4(5H)-yl)-3-(diphenylphosphino)propan-1-one (40). Using the procedure described for the synthesis of the amidophosphine 30, the amidophosphine 40 (85\%) was obtained as a white solid. ${ }^{1} \mathrm{H}-\mathrm{NMR}\left(500 \mathrm{MHz}, \mathrm{CDCl}_{3}\right) \delta 8.00(\mathrm{t}, J=9.2 \mathrm{~Hz}, 4 \mathrm{H}), 7.68(\mathrm{~d}, J=8.4 \mathrm{~Hz}, 1 \mathrm{H})$, 7.56-7.52 (m, 7H), 7.50-7.47 (m, 1H), 7.43-7.39 (m, 7H), 7.35-7.31 (m, 2H), $5.53(\mathrm{~d}, J=13.5 \mathrm{~Hz}$, $1 \mathrm{H}), 4.51(\mathrm{~d}, J=12.9 \mathrm{~Hz}, 1 \mathrm{H}), 3.88(\mathrm{~d}, J=12.9 \mathrm{~Hz}, 1 \mathrm{H}), 3.56(\mathrm{~d}, J=13.5 \mathrm{~Hz}, 1 \mathrm{H}), 2.73-2.66(\mathrm{~m}$, 1H), 2.57-2.47 (m, 3H); ${ }^{13} \mathrm{C}-\mathrm{NMR}\left(125 \mathrm{MHz}, \mathrm{CDCl}_{3}\right) \delta 170.3(\mathrm{~d}, J=15.1 \mathrm{~Hz}), 138.1(\mathrm{~d}, J=18.7 \mathrm{~Hz})$, $137.9(\mathrm{~d}, J=18.7 \mathrm{~Hz}), 135.2,134.8,133.3,133.2,133.0,132.7(\mathrm{~d}, J=6.4 \mathrm{~Hz}), 132.6(\mathrm{~d}, J=6.4 \mathrm{~Hz})$, 132.0, 131.3, 131.2, 129.2 (d, $J=6.4 \mathrm{~Hz}), 128.7(\mathrm{~d}, J=3.6 \mathrm{~Hz}), 128.5(\mathrm{~d}, J=6.6 \mathrm{~Hz}), 128.2(\mathrm{~d}$, $J=4.3 \mathrm{~Hz}), 127.7,127.4,127.2,126.7,126.2,126.0,125.8,49.1,46.3,30.6$ (d, $J=19.9 \mathrm{~Hz}), 23.2(\mathrm{~d}$, $J=11.0 \mathrm{~Hz}) ;{ }^{31} \mathrm{P}-\mathrm{NMR}\left(202 \mathrm{MHz}, \mathrm{CDCl}_{3}\right) \delta-14.1$.

(S)-4-(3-(Diphenylphosphino)propyl)-4,5-dihydro-3H-dinaphtho[2,1-c:1',2'-e]azepine (41). Using the procedure described for the synthesis of the aminophosphine 31, the aminophosphine 41 (83\%) was obtained as a white solid. ${ }^{1} \mathrm{H}-\mathrm{NMR}\left(500 \mathrm{MHz}, \mathrm{CDCl}_{3}\right) \delta 7.99(\mathrm{t}, J=8.0 \mathrm{~Hz}, 4 \mathrm{H}), 7.51(\mathrm{q}, J=8.0 \mathrm{~Hz}$, $10 \mathrm{H}), 7.39$ (t, $J=6.2 \mathrm{~Hz}, 6 \mathrm{H}), 7.31$ (t, $J=7.6 \mathrm{~Hz}, 2 \mathrm{H}), 3.67$ (d, $J=12.4 \mathrm{~Hz}, 2 \mathrm{H}), 3.19$ (d, $J=12.4 \mathrm{~Hz}$, 2H), 2.76-2.70 (m, 1H), 2.56-2.50 (m, 1H), $2.18(\mathrm{t}, J=7.7 \mathrm{~Hz}, 2 \mathrm{H}), 1.83-1.76(\mathrm{~m}, 2 \mathrm{H}) ;{ }^{13} \mathrm{C}-\mathrm{NMR}$ $\left(125 \mathrm{MHz}, \mathrm{CDCl}_{3}\right) \delta 138.7(\mathrm{~d}, J=22.4 \mathrm{~Hz}), 138.6(\mathrm{~d}, J=22.4 \mathrm{~Hz}), 134.8,133.5,133.0,132.7(\mathrm{~d}$, $J=4.5 \mathrm{~Hz}), 132.6(\mathrm{~d}, J=4.5 \mathrm{~Hz}), 131.3,128.4,128.32,128.27,128.15,128.11,127.6,127.3,125.6$, 125.2, $56.3(\mathrm{~d}, J=13.9 \mathrm{~Hz}), 55.2,25.7(\mathrm{~d}, J=11.5 \mathrm{~Hz}), 24.4(\mathrm{~d}, J=16.5 \mathrm{~Hz}) ;{ }^{31} \mathrm{P}-\mathrm{NMR}(202 \mathrm{MHz}$, $\left.\mathrm{CDCl}_{3}\right) \delta-14.7$.

1-(2,6-Di(naphthalen-2-yl)-3H-dinaphtho[2,1-c:1',2'-e]azepin-4(5H)-yl)-3-(diphenylphosphino)propan1-one (57). Using the procedure described for the synthesis of the amidophosphine 40, the amidophosphine 57 was obtained as a light-yellow foam $(63 \%) .{ }^{1} \mathrm{H}-\mathrm{NMR}\left(500 \mathrm{MHz}, \mathrm{CDCl}_{3}\right) \delta 8.06$ (s, 1H), 8.03-8.01 (m, 4H), 7.98-7.89 (m, 10H), 7.68 (app t, $J=7.7 \mathrm{~Hz}, 2 \mathrm{H}), 7.60-7.55(\mathrm{~m}, 6 \mathrm{H})$, $7.43-7.38(\mathrm{~m}, 3 \mathrm{H}), 7.35-7.31(\mathrm{~m}, 6 \mathrm{H}), 7.28-7.25(\mathrm{~m}, 2 \mathrm{H}), 7.15(\mathrm{~d}, J=8.5 \mathrm{~Hz}, 1 \mathrm{H}), 5.00$ (app t, $J=4.6 \mathrm{~Hz}, 1 \mathrm{H}), 4.50$ (app dd, $J=13.9,5.6 \mathrm{~Hz}, 1 \mathrm{H}), 4.17$ (app dd, $J=14.1,3.9 \mathrm{~Hz}, 1 \mathrm{H}), 183-1.77$ (m, 2H), $1.62-1.53(\mathrm{~m}, 2 \mathrm{H}) ;{ }^{13} \mathrm{C}-\mathrm{NMR}\left(125 \mathrm{MHz}, \mathrm{CDCl}_{3}\right) \delta 170.4(\mathrm{~d}, J=15.3 \mathrm{~Hz}), 141.3,140.8,139.4$, $138.4(\mathrm{~d}, J=10.0 \mathrm{~Hz}), 134.8,133.23,133.16,133.1,132.9,132.6$ (d, $J=4.5 \mathrm{~Hz}), 132.5$ (d, $J=4.5 \mathrm{~Hz})$, $132.4,132.3,131.9,131.8,129.7,129.0,128.54,128.52,128.33,128.31,128.25,127.98,127.96$, $127.88,127.7,127.6,127.5,127.3,126.7,126.6,126.42,126.39,126.2,126.13,126.07,125.9,125.5$, 125.0, 40.2, $31.9(\mathrm{~d}, J=18.1 \mathrm{~Hz}), 22.8(\mathrm{~d}, J=12.0 \mathrm{~Hz}) ;{ }^{31} \mathrm{P}-\mathrm{NMR}\left(202 \mathrm{MHz}, \mathrm{CDCl}_{3}\right) \delta-14.2$.

4-(3-(Diphenylphosphino)propyl)-2,6-di(naphthalen-2-yl)-4,5-dihydro-3H-dinaphtho[2,1-c:1',2'-e]azepine (58). Using the procedure described for the synthesis of the aminophosphine 41, the aminophosphine $58(55 \%)$ was obtained as a light-yellow foam. ${ }^{1} \mathrm{H}-\mathrm{NMR}\left(500 \mathrm{MHz}, \mathrm{CDCl}_{3}\right) \delta 8.11$ (br s, $\left.2 \mathrm{H}\right), 8.08$ (s, 2H), $8.01(\mathrm{~d}, J=8.1 \mathrm{~Hz}, 2 \mathrm{H}), 7.90-7.82(\mathrm{~m}, 7 \mathrm{H}), 7.58(\mathrm{~d}, J=8.6 \mathrm{~Hz}, 2 \mathrm{H}), 7.56-7.49$ (m, 7H), 7.34 (app t, $J=7.4 \mathrm{~Hz}, 2 \mathrm{H}), 7.31-7.27(\mathrm{~m}, 3 \mathrm{H}), 7.22(\operatorname{app~t}, J=7.3 \mathrm{~Hz}, 5 \mathrm{H}), 7.14(\operatorname{app~t}, J=7.1 \mathrm{~Hz}, 2 \mathrm{H})$, $3.99(\mathrm{~d}, J=12.4 \mathrm{~Hz}, 2 \mathrm{H}), 3.15(\mathrm{~d}, J=11.8 \mathrm{~Hz}, 2 \mathrm{H}), 2.19-2.15(\mathrm{~m}, 1 \mathrm{H}), 2.07-2.01(\mathrm{~m}, 1 \mathrm{H}), 1.67$ (br s, 
$1 \mathrm{H}) ;{ }^{13} \mathrm{C}-\mathrm{NMR}\left(125 \mathrm{MHz}, \mathrm{CDCl}_{3}\right) \delta 140.3,138.9,136.2,133.2,132.6,132.5,132.4,132.3,131.9$, $130.8,129.3,128.6,128.4,128.3,128.1,128.09,128.08,128.0,127.7,127.5,126.2,125.9,125.8$, 125.7, $55.0(\mathrm{~d}, J=13.2 \mathrm{~Hz}), 50.6,25.2(\mathrm{~d}, J=11.4 \mathrm{~Hz}), 23.5(\mathrm{~d}, J=15.6 \mathrm{~Hz}) ;{ }^{31} \mathrm{P}-\mathrm{NMR}(202 \mathrm{MHz}$, $\left.\mathrm{CDCl}_{3}\right) \delta-14.3$.

\section{Conclusion}

Because the bisphosphine-catalyzed double-Michael reaction is an efficient methodology for synthesizing 5- and 6-membered heterocycles, we sought an asymmetric variant of the reaction, employing a chiral bisphosphine catalyst. Several common and commercially available bisphosphines were only marginally successful at catalyzing a double-Michael indoline synthesis. After establishing that the aminophosphine $\mathbf{4 2}$ was as efficient as bisphosphine at facilitating the double-Michael reaction, we prepared a series of chiral aminophosphines.

The synthesis of a chiral aminophosphine is simpler than that of a chiral bisphosphine because of the availability of a wide variety of chiral amines found in Nature and the ease of preparing and handling chiral amines. We prepared a series of aminophosphines featuring tethers of two or three carbon atoms, derived from an acyclic chiral amine, L-proline, and $(S)$-binol, and employed them as catalysts in the double-Michael indoline synthesis. Despite the impractical enantioselectivities provided by these aminophosphines, we are encouraged by some slight improvements in enantioinduction relative to those of bisphosphines. Notably, however, we obtained these poor levels of enantioinduction using only one type of substrate under one specific set of conditions; therefore, we should not dismiss the use of chiral aminophosphines in double-Michael indoline syntheses until we have subjected the systems to further investigation. To the best of our knowledge, no literature precedent exists for chiral induction through intramolecular anchimeric assistance. Therefore, it remains a novel and a very challenging task to discover an appropriate aminophosphine for the asymmetric variant of the double-Michael addition and to verify the feasibility of chiral induction through intramolecular anchimeric assistance.

\section{Acknowledgments}

Financial support was provided by the NIH (R01GM071779 and P41GM081282).

\section{References}

1. Yamada, K., Kinoshita, S., Tsunoda, T., Aida, K., Eds. The Microbial Production of Amino Acids; John Wiley \& Son: New York, NY, USA, 1972.

2. Dalko, P.I. Asymmetric Organocatalysis: A New Stream in Organic Synthesis. In Enantioselective Organocatalysis: Reactions and Experimental Procedures; Dalko, P.I., Ed.; Wiley-VCH: Darmstadt, Germany, 2007; pp. 1-13.

3. Kagan, H.B.; Gopalaiah, K. Early history of asymmetric synthesis: Who are the scientists who set up the basic principles and the first experiments? New J. Chem. 2011, 35, 1933-1937.

4. Bredig, G.; Balcom, R.W. Kinetik der Kohlendioxyd-abspaltung aus Camphocarbonsäure. Ber. Deutsch. Chem. Ger. 1908, 41, 740-751. 
5. Bredig, G.; Fajans, K. Zur Stereochemie der Katalyse. Ber. Deutsch. Chem. Ger. 1908, 41, 752-763.

6. Bredig, G.; Fiske, P.S. Durch Katalysatoren bewirkte Asymmetrische Synthese. Biochem. Zeits. 1912, 46, 7-23.

7. Pracejus, H. Organische Katalysatoren, LXI. Asymmetrische Synthesen mit Ketenen, I. Alkaloid-katalysierte asymmetrische Synthesen von $\alpha$-Phenyl-propionsäureestern. Justus Liebigs Ann. Chem. 1960, 634, 9-22.

8. Knowles, W.S.; Sabacky, M.J. Catalytic asymmetric hydrogenation employing a soluble, optically active, rhodium complex. Chem. Commun. 1968, 22, 1445-1446.

9. Knowles, W.S.; Sabacky, M.J.; Vineyard, B.D. Catalytic asymmetric hydrogenation using soluble, optically active phosphine complexes. Ann. NY Acad. Sci. 1970, 172, 232-237.

10. Knowles, W.S.; Sabacky, M.J.; Vineyard, B.D. Catalytic asymmetric hydrogenation. J. Chem. Soc. Chem. Commun. 1972, 1, 10-11.

11. Knowles, W.S.; Sabacky, M.J.; Vineyard, B.D.; Weinkauff, D.J. Asymmetric hydrogenation with a complex of rhodium and a chiral bisphosphine. J. Am. Chem. Soc. 1975, 97, 2567-2568.

12. Knowles, W.S. Asymmetric hydrogenation. Acc. Chem. Res. 1983, 16, 106-112.

13. Knowles, W.S. Asymmetric hydrogenations. Adv. Synth. Cat. 2003, 345, 3-13.

14. Komarov, I.V.; Börner, A. Highly enantioselective or not? Chiral monodentate monophosphorus ligands in the asymmetric hydrogenation. Angew. Chem. Int. Ed. Engl. 2001, 40, 1197-1200.

15. Crépy, K.V.L.; Imamoto, T. Recent developments in catalytic asymmetric hydrogenation employing P-chirogenic diphosphine ligands. Adv. Synth. Catal. 2003, 345, 79-101.

16. Hajos, Z.G.; Parrish, D.R.W. Werkwijze Voor de Bereiding van 1,3-Dioxycycloackanen. German Patent DE 2102623, 1971.

17. Hajos, Z.G.; Parrish, D.R. Asymmetric synthesis of bicyclic intermediates of natural product chemistry. J. Org. Chem. 1974, 39, 1615-1621.

18. Eder, U.; Sauer, G.; Wiechert, R. Process for the Manufacture of Optically Active Bicycloalkane Derivatives. German Patent DE 2014757, 1971.

19. Eder, U.; Sauer, G.; Wiechert, R. New type of asymmetric cyclization to optically active steroid CD partial structures. Angew. Chem. Int. Ed. Engl. 1971, 10, 496-497.

20. List, B.; Yang, J.W. The organic approach to asymmetric catalysis. Science 2006, 313, 1584-1586.

21. MacMillan, D.W.C. The advent and development of organocatalysis. Nature 2008, 455, 304-308.

22. List, B. Asymmetric Organocatalysis, 1st ed.; Springer: Heidelberg, Germany, 2010; Volume 291, pp. 1-458.

23. Sriramurthy, V.; Barcan, G.A.; Kwon, O. Bisphosphine-catalyzed mixed double-michael reactions: Asymmetric synthesis of oxazolidines, thiazolidines, and pyrrolidines. J. Am. Chem. Soc. 2007, 129, 12928-12929.

24. Sriramurthy, V.; Kwon, O. Diphosphine-catalyzed mixed double-Michael reaction: A unified synthesis of indolines, dihydropyrrolopyridines, benzimidazolines, tetrahydroquinolines, tetrahydroisoquinolines, dihydrobenzo-1,4-oxazines, and dihydrobenzo-3,1-oxazines. Org. Lett. 2010, 12, 1084-1087. 
25. Fan, Y.C.; Kwon, O. Diversity-oriented synthesis based on the DPPP-catalyzed mixed double-Michael reactions of electron-deficient acetylenes and $\beta$-amino alcohols. Molecules 2011, $16,3802-3825$.

26. Kisanga, P.B.; Verkade, J.G. $\mathrm{pK}_{\mathrm{a}}$ Measurements of $\mathrm{P}\left(\mathrm{RNCH}_{2} \mathrm{CH}_{3}\right)_{3} \mathrm{~N}$. J. Org. Chem. 2000, 65, 5431-5432.

27. Kisanga, P.B.; Ilankumaran, P.; Fetterly, B.M.; Verkade, J.G. P( $\left(\mathrm{RNCH}_{2} \mathrm{CH}_{2}\right)_{3} \mathrm{~N}$ : Efficient 1,4-addition catalysts. J. Org. Chem. 2002, 67, 3555-3560.

28. Verkade, J.G.; Kisanga, P.B. Recent applications of proazaphosphatranes in organic synthesis. Aldrichimica Acta 2004, 1, 3-14.

29. Sriramurthy, V.; Kwon, O. University of California, Los Angeles, CA, USA. Chiral 4-(N,N-dialkyl)aminomethyl-5-diphenylphosphinomethyl-1,3-dioxolane, 2012.

30. Blinn, D.A.; Button, R.S.; Farazi, V.; Neeb, M.K.; Tapley, C.L.; Treheame, T.E.; West, S.D.; Kruger, T.L.; Storhoff, B.N. Addition of diphenylphosphine to Michael-type olefins: The preparation of phosphine-nitrile and phosphine-ester ligands. J. Organomet. Chem. 1990, 393, 143-152.

31. Shi, M.; Chen, L.-H.; Li, C.-Q. Chiral phosphine Lewis bases catalyzed asymmetric aza-BaylisHillman reaction of $N$-sulfonated imines with activated olefins. J. Am. Chem. Soc. 2005, 127, 3790-3800.

32. Jiang, Y.-Q.; Shi, Y.-L.; Shi, M. Chiral phosphine-catalyzed enantioselective construction of $\gamma$-butenolides through substitution of Morita-Baylis-Hillman acetates with 2-trimethylsilyloxy furan. J. Am. Chem. Soc. 2008, 130, 7202-7203.

33. Cowen, B.J.; Miller, S.J. Enantioselective [3+2]-cycloadditions catalyzed by a protected, multifunctional phosphine-containing $\alpha$-amino acid. J. Am. Chem. Soc. 2007, 129, 10988-10989.

34. Xiao, H.; Chai, Z.; Zheng, C.-W.; Yang, Y.-Q.; Liu, W.; Zhang, J.-K.; Zhao, G. Asymmetric $[3+2]$ cycloadditions of allenoates and dual activated olefins catalyzed by simple bifunctional $N$-acyl aminophosphines. Angew. Chem. Int. Ed. Engl. 2010, 49, 4467-4470.

35. Cao, D.-D.; Liu, W.; Lu, Y.-P.; Yang, Y.-Q.; Zhao, G. Bifunctional N-acyl-aminophosphinecatalyzed asymmetric [4+2] cycloadditions of allenoates and imines. Chem. Eur. J. 2011, 17, 10562-10565.

36. List, B. Proline-catalyzed asymmetric reactions. Tetrahedron 2002, 58, 5573-5590.

37. List, B. Enamine catalysis is a powerful strategy for the catalytic generation and use of carbanion equivalents. Acc. Chem. Res. 2004, 37, 548-557.

38. Whitesell, J.K. $C_{2}$ Symmetry and asymmetric induction. Chem. Rev. 1989, 89, 1581-1590.

39. Vogl, E.M.; Matsunaga, S.; Kanai, M.; Iida, T.; Shibasaki, M. Linking BINOL: $C_{2}$-Symmetric ligands for investigations on asymmetric catalysis. Tetrahedron Lett. 1998, 39, 7917-7920.

40. Noyori, R.; Takaya, H. BINAP: An efficient chiral element for asymmetric catalysis. Acc. Chem. Res. 1990, 23, 345-350.

41. Noyori, R. Asymmetric catalysis: Science and opportunities. Angew. Chem. Int. Ed. Engl. 2002, 41, 2008-2022.

42. Chen, Y.; Yekta, S.; Yudin, A.K. Modified BINOL ligands in asymmetric catalysis. Chem. Rev. 2003, 103, 3155-3212. 
43. Ooi, T.; Kameda, M.; Maruoka, K. Design of $\mathrm{N}$-spiro $C_{2}$-symmetric chiral quaternary ammonium bromides as novel chiral phase-transfer catalysts: Synthesis and application to practical asymmetric synthesis of $\alpha$-amino acids. J. Am. Chem. Soc. 2003, 125, 5139-5151.

44. Demuth, M.; Mikhail, G. A convenient in situ preparation of trimethylsilyl trifluoromethanesulfonate. Synthesis 1982, 10, 827.

45. Demuth, M.; Mikhail, G. Electrophile-initiated selective ring transformations of cyclopropyl ketones. Tetrahedron 1983, 39, 991-997.

46. Eastham, G.R.; Waugh, M.; Pringle, P.; Fanjul Solares, T. Process for the Carbonylation of Ethylenically Unsaturated Compounds, Novel Carbonylation Ligands and Catalyst Systems Incorporating such Ligands. WO/2010/001174, 2010.

47. Gulyás, H.; Benet-Buchholz, J.; Escudero-Adan, E.C.; Freixa, Z.; van Leeuwen, P.W.N.M. Ionic interaction as a powerful driving force for the formation of heterobidentate assembly ligands. Chem. Eur. J. 2007, 13, 3424-3430.

48. Adams, H.; Bawa, R.A.; McMillan, K.G.; Jones, S. Asymmetric control in Diels-Alder cycloadditions of chiral 9-aminoanthracenes by relay of stereochemical information. Tetrahedron: Asymmetry 2007, 18, 1003-1012.

49. Galbo, F.L.; Occhiato, E.G.; Guarna, A.; Faggi, C. Preparation and cycloaddition reactions of enantiopure 2-( $N$-acylamino)-1,3-dienes for the synthesis of octahydroquinoline derivatives. J. Org. Chem. 2003, 68, 6360-6368.

50. Wallén, E.A.A.; Christiaans, J.A.M.; Saario, S.M.; Forsberg, M.M.; Venäläinen, J.I.; Paso, H.M.; Männistö, P.T.; Gynthera, J. 4-Phenylbutanoyl-2(S)-acylpyrrolidines and 4-phenylbutanoyl-Lprolyl-2(S)-acylpyrrolidines as prolyl oligopeptidase inhibitors. Bioorg. Med. Chem. 2002, 10, 2199-2206.

51. Alza, E.; Cambeiro, X.C.; Jimeno, C.; Pericàs, M.A. Highly enantioselective Michael additions in water catalyzed by a PS-supported pyrrolidine. Org. Lett. 2007, 9, 3717-3720.

52. Havran, L.M.; Chong, D.C.; Childers, W.E.; Dollings, P.J.; Dietrich, A.; Harrison, B.L.; Marathias, V.; Tawa, G.; Aulabaugh, A.; Cowling, R.; et al. 3,4-Dihydropyrimido(1,2- $\alpha$ )indol$10(2 \mathrm{H})$-ones as potent non-peptidic inhibitors of caspase-3. Bioorg. Med. Chem. 2009, 17, 7755-7768.

53. Dokuzovič, Z.; Roberts, N.K.; Sawyer, J.F.; Whelan, J.; Bosnich, B. Asymmetric synthesis. Metal complex mediated synthesis of chiral glycine by enantioselective proton exchange. J. Am. Chem. Soc. 1986, 108, 2034-2039.

54. Kanai, M.; Nakagawa, Y.; Tomioka, K. An asymmetric conjugate addition reaction of lithium organocopper reagent controlled by a chiral amidophosphine. Tetrahedron 1999, 55, 3831-3842.

55. Bartoli, G.; Bosco, M.; Dalpozzo, R.; Giuliani, A.; Marcantoni, E.; Mecozzi, T.; Sambri, L.; Torregiani, E. An efficient procedure for the preparation of $(E)$ - $\alpha$-alkylidenecycloalkanones mediated by a $\mathrm{CeCl}_{3} \cdot 7 \mathrm{H}_{2} \mathrm{O}-\mathrm{NaI}$ system. Novel methodology for the synthesis of $(S)-(-)$-pulegone. J. Org. Chem. 2002, 67, 9111-9114.

56. Hayashi, T.; Konishi, M.; Fukushima, M.; Kanehira, K.; Hioki, T.; Kumada, M. Chiral ( $\beta$-aminoalkyl)phosphines. Highly efficient phosphine ligands for catalytic asymmetric Grignard cross-coupling. J. Org. Chem. 1983, 48, 2195-2202. 
57. Gautier, F.-M.; Jones, S.; Martin, S. Asymmetric reduction of ketimines with trichlorosilane employing an imidazole derived organocatalyst. J. Org. Biomol. Chem. 2009, 7, 229-231.

58. Kobayashi, S.; Kinoshita, T.; Uehara, H.; Sudo, T.; Ryu, I. Organocatalytic enantioselective synthesis of nitrogen-substituted dihydropyran-2-ones, a key synthetic intermediate of 1 $\beta$-methylcarbapenems. Org. Lett. 2009, 11, 3934-3937.

Sample Availability: Samples of compounds 21, 40, and $\mathbf{4 1}$ are available from the authors.

(C) 2012 by the authors; licensee MDPI, Basel, Switzerland. This article is an open access article distributed under the terms and conditions of the Creative Commons Attribution license (http://creativecommons.org/licenses/by/3.0/). 